NBER WORKING PAPER SERIES

\title{
ARE TRADE LINKAGES IMPORTANT DETERMINANTS OF COUNTRY VULNERABILITY TO CRISES?
}

\author{
Kristin J. Forbes \\ Working Paper 8194 \\ http://www.nber.org/papers/w8194
}

\author{
NATIONAL BUREAU OF ECONOMIC RESEARCH \\ 1050 Massachusetts Avenue \\ Cambridge, MA 02138 \\ March 2001
}

Paper prepared for the NBER conference Currency Crises Prevention held in January 2001 in Islamorada, Florida. Thanks to Sebastian Edwards, Jeffrey Frankel, Frederico Sturzenegger and conference participants for useful suggestions and comments. The views expressed herein are those of the author and not necessarily those of the National Bureau of Economic Research.

(C) 2001 by Kristin J. Forbes. All rights reserved. Short sections of text, not to exceed two paragraphs, may be quoted without explicit permission provided that full credit, including $\mathbb{C}$ notice, is given to the source. 
Are Trade Linkages Important Determinants of Country Vulnerability to Crises?

Kristin J. Forbes

NBER Working Paper No. 8194

March 2001

JEL No. F10, F36, F40, G15

\begin{abstract}
This paper measures whether trade linkages are important determinants of a country's vulnerability to crises that originate elsewhere in the world. It explains that trade can transmit crises internationally via three distinct, and possible counteracting, channels: a competitiveness effect (when changes in relative prices affect a country's ability to compete abroad); an income effect (when a crisis affects incomes and the demand for imports); and a cheap-import effect (when a crisis reduces import prices and acts as a positive supply shock). Next, the paper develops a series of statistics measuring each of these trade linkages for a sample of 58 countries during 16 crises from 1994 through 1999. Of particular interest is the competitiveness statistic, which uses 4-digit industry information to calculate how each crisis affects exports from other countries. Empirical results suggest that countries which compete with exports from a crisis country and which export to the crisis country (i.e. the competitiveness and income effects) had significantly lower stock market returns. Although trade linkages only partially explain stock market returns during recent crises, they are significant and economically important.
\end{abstract}

Kristin J. Forbes

MIT-Sloan School of Management

50 Memorial Drive, E52-446

Cambridge, MA 02142-1347

and NBER

kjforbes@mit.edu

http://web.mit.edu/kjforbes/www/ 


\section{Introduction}

The later half of the 1990's was punctuated by a series of financial and currency crises: the Mexican peso collapse in 1994; the East Asian crisis in 1997-98; the Russian collapse in 1998; and the devaluations in Brazil and Ecuador in 1999. One striking characteristic of many of these crises was how an initial country-specific event was rapidly transmitted to markets of very different sizes and structures around the globe. These events have prompted a surge of interest in "contagion" and the determinants of a country's vulnerability to crises that originate elsewhere in the world. Despite this interest, however, there continues to be little agreement on why many of these crises that began in relatively small economies had such large global repercussions.

One channel through which a country-specific crisis could have global repercussions is trade. If two countries trade directly, export to the same country (or countries), or simply compete in the same industries, then a crisis in one of the countries could change the relative prices and/or quantities of goods traded by that country and have spillover effects in the other economy. Theoretical models have shown exactly how these trade linkages could transmit a crisis in one country to another country. There is an ongoing debate, however, on whether these trade linkages have been large and/or significant determinants of how different countries were affected by recent financial crises.

Informal evidence suggests why this debate is unresolved. There is little direct trade between Brazil and Russia, and even minimal competition in third markets between these two countries. Brazil, however, was severely impacted by the Russian crisis in 1998, suggesting that trade linkages may not have been important in the transmission of 
this crisis. On the other hand, Argentina is one of Brazil's major trading partners. Argentina is also one of the countries most affected by Brazil's devaluation in 1999, suggesting that trade may have been important in the transmission of the Brazilian crisis. Numerous other examples from the series of currency crises in the 1990's could support either of these arguments.

This paper addresses the debate on whether trade linkages were important determinants of countries' vulnerability to recent currency crises. It decomposes "trade linkages" into three channels by which a country could be affected by a crisis elsewhere in the world: a competitiveness effect (when changes in relative prices affect a country's ability to compete abroad); an income effect (when a crisis affects incomes and the demand for imports); and a cheap-import effect (when a crisis reduces import prices for a trading partner and acts as a positive supply shock). Then it uses data on aggregate trade flows and 4-digit industry trade flows to measure the strength of these three channels between every country experiencing a crisis from 1994 through 1999 and a sample of developed and developing countries around the world.

Using these statistics, the paper estimates how trade linkages affect a country's stock market returns during recent crises. It finds that the competitiveness and income effects are both negative, significant, and economically important. In other words, if a country competes in the same industries as a crisis country, or exports directly to the crisis country, then the country will have significantly lower stock returns during the crisis. There is also weak evidence of a positive cheap-import effect. The combined impact of these three trade linkages appears to be much greater than that of other macroeconomic variables. These trade linkages, however, only explain about one-quarter 
of the variation in stock market returns during recent crises, suggesting that other crosscountry linkages, such as financial channels, may also be important.

A final result from this empirical analysis is that how a country responds to a currency crisis is an important determinant of how the crisis impacts other economies. For example, some countries respond to pressure on their exchange rate by devaluing their currency (or allowing it to depreciate). Other countries attempt to maintain a stable currency value and instead increase interest rates significantly. Other countries pay out international reserves, or use some combination of these three defenses. Empirical results suggest that the competitiveness effect is only large and significant when a crisis country allows its currency to be devalued (or depreciate) substantially. Results also suggest that the income effect is only large and significant when a crisis country raises interest rates substantially. Therefore, the importance of trade linkages depends on how a country responds to the initial crisis. This has important implications for preventing and predicting how future crises spread internationally.

This paper makes a number of contributions to the literature. First, it emphasizes that "trade" actually captures several different, and possibly counteracting, channels that can be divided into three distinct effects: a competitiveness, income, and cheap-import effect. Second, it creates a number of new and more accurate statistics to measure these trade linkages. For example, most papers attempting to measure trade competition in third markets analyze aggregate trade flows to common markets. Just because two countries are highly dependent on a common market, however, does not mean that the two countries compete directly. For example, if a high proportion of Saudi Arabia's oil and of Brazil's coffee goes to the same third market, Saudi Arabia and Brazil are not direct 
competitors. By focusing on trade in specific industries, instead of aggregate trade flows, this paper's statistics provide more accurate measures of trade competition.

Fourth and finally, by utilizing this industry-level trade data, the paper can reduce any omitted-variables bias. More specifically, several papers which find that trade linkages help transmit crises admit that trade flows are highly correlated with financial flows. It is extremely difficult to disentangle these linkages (and even to measure financial linkages), so estimates of the importance of trade linkages may actually be capturing the impact of financial linkages. ${ }^{1}$ Financial flows are generally country specific and similar across industries, however, while many trade flows vary across industries. Therefore, by using industry-level data this paper can more accurately identify the impact of trade linkages and reduce any omitted-variables bias.

The remainder of this paper is as follows. Section II reviews previous empirical work assessing the importance of trade in the international transmission of crises. Section III surveys the related theoretical work and then uses this work to decompose trade into three different (and possibly opposing) linkages. Section IV uses an index of exchange rates, interest rates, and reserve levels to identify the crisis events used in the rest of the paper. Section V introduces the model and data set and calculates a number of statistics measuring trade linkages across countries. It discusses these statistics, and especially the industry-based competitiveness measure, in some detail. Section VI presents regression estimates, including an extensive series of sensitivity tests. It finds that competitiveness and income effects are significant and economically important determinants of country vulnerability to crises. Section VII examines different types of crises and shows that how

\footnotetext{
${ }^{1}$ Glick and Rose (1999), Kaminsky and Reinhart (2000), and Van Rijckeghem and Weder (2001) all raise this point.
} 
a country responds to exchange-market pressure determines which trade linkages are important transmission mechanisms. Finally, Section VIII summarizes the key results of the paper and concludes with an important policy implication.

\section{The Empirical Literature: Is Trade Important?}

A number of empirical papers have attempted to measure the importance of trade in the international transmission of crises. This section discusses the basic methodology and results of each of these papers. It begins with three empirical papers which argue that trade linkages are important determinants of how crises spread. Then it discusses three papers which claim that trade linkages were not important during recent crises. The section concludes by summarizing three recent papers which argue that trade linkages are important, but overshadowed by other transmission mechanisms.

One of the first empirical papers to assess the importance of trade and find strong support for this propagation mechanism was Eichengreen and Rose (1999). This paper uses a binary-probit model to test whether the probability of a crisis occurring in twenty industrial countries between 1959 and 1993 is correlated with the occurrence of a speculative attack in other countries at the same time. In one series of tests, the authors weight the occurrence of crises in other countries by a trade matrix (which is based on bilateral trade flows in manufacturing ${ }^{2}$ ) and by a matrix of macroeconomic variables. They find that this trade-weighted matrix is highly significant and robust, while the macro-weighted matrix is insignificant. They conclude that their results lend "some

\footnotetext{
${ }^{2}$ More specifically, this weighting matrix is based on the MERM weights constructed by the International Monetary Fund and used to compute its real effective multilateral exchange rates. The weights are based on unit labor costs, use a convex combination of import and export trade flows, were created in October of 1994 and are time-invariant.
} 
support to our favored interpretation that it is trade links rather than macroeconomic similarities that have been the dominant channel for the contagious transmission in the sample period." ${ }^{3}$

Glick and Rose (1999) build on this framework in the most complete and thorough analysis, to date, of the role of trade in the international transmission of crises. They focus on five major currency crises between 1971 and 1997 and test if the probability of a country being attacked during a crisis is affected by trade linkages between that country and the crisis country. Glick and Rose include a much larger sample of countries than Eichengreen and Rose and use a number of different statistics to measure trade linkages. They focus on a trade statistic measuring exports to common third markets, although they also run sensitivity tests using: bilateral trade flows; a combination of these two statistics; and exports to common markets weighted by country size. These trade measures are consistently large and significant, indicating that: "a stronger trade linkage is associated with a higher incidence of currency crises." ${ }^{4}$ Once again, macroeconomic controls are generally insignificant.

Instead of using aggregate trade flow data, Forbes (2000) utilizes firm-level information to measure the importance of trade in the international transmission of crises. The paper's sample includes information on over 10,000 companies from around the world during the Asian and Russian crises. It focuses on the variation in different company's stock market performance, which not only tests which types of companies were most affected by these crises, but also how these crises spread internationally. Results show that companies which had sales exposure to the crisis country and/or

\footnotetext{
${ }^{3}$ Eichengreen and Rose (1999), pg. 50. The working paper version was Eichengreen, Rose, and Wyplosz (1996).
} 
competed in the same industries as crisis-country exports had significantly lower stock returns during these two crises. The paper concludes that direct trade effects (called income effects) as well as competition in export industries (called productcompetitiveness effects) "were both important transmission mechanisms during the later part of the Asian crisis and the Russian crisis."

Although these three papers find strong evidence for the role of trade, a number of other empirical papers argue that trade was not important in the propagation of recent crises. In one of the earliest papers classifying specific channels through which crises spread internationally, Masson (1998) categorizes trade as a "spillover" and argues that spillovers were not important during the 1994 Mexican crisis or the 1997 Asian crisis. He argues that since exports to Mexico and Thailand constituted a small proportion of total exports from their neighbors, regional spillover effects through trade would have been modest. Masson also calculates the loss in competitiveness of five Asian countries (as measured by changes in their real effective exchange rates) during the Asian crisis. Since this competitiveness effect was small (at least before the November depreciation of the won), he argues that these spillovers cannot explain the spread of the crisis from Thailand throughout Asia. Masson concludes that: spillover effects "cannot explain the coincidence of speculative pressures felt by a number of emerging market economies at the time of the Mexican and Thai crises." ${ }^{6}$

Baig and Goldfajn (1998) also argue that trade was not important in the spread of the Asian crisis. They calculate direct trade flows between each of the East Asian economies and assert: "...they are not adequate to account for what happened in East

\footnotetext{
${ }^{4}$ Glick and Rose (1999), pg. 613.

${ }^{5}$ Forbes (2000), abstract.
} 
Asia. The trade linkages among the five countries in discussion are not very striking...The export share to Thailand constituted less than 4 percent of total exports for each of the four countries in discussion, making intra-country trade an unlikely source of pressure on financial markets." Baig and Goldfajn also consider indirect trade linkages, such as export competition in the U.S. and Japan, but "...don't find much evidence in support of this argument either. The Asia 5 countries do not share very similar thirdcountry export profiles that would amount to severe competitiveness pressures."7

A final paper which argues that trade was not significant has a more limited focus. Harrigan (2000) examines how the Asian crisis affected prices and volumes in different U.S. manufacturing sectors. He concludes that: "The impact of the Asia[n] crisis on U.S. industries was small and localized. Only one sector, the steel industry, experienced falling prices and output in the wake of the crisis..." ${ }^{8}$ Harrigan admits that there was a decreased demand for U.S. manufactured goods in Asia during the crisis, but claims that this was offset by increased demand elsewhere in the world (including within the U.S.) He also reports that U.S. import volumes from Asia only increased moderately during this period, despite the large fall in import prices, because U.S. demand for Asian imports is relatively inelastic.

These three papers argue that trade was not important in the international transmission of recent crises, and the first three papers discussed in this section argue that trade was important. Most recent empirical work, however, takes an intermediate stance and claims that trade linkages can have some role, but are generally overshadowed by

\footnotetext{
${ }^{6}$ Masson (1998), pg. 3.

${ }^{7}$ Baig and Goldfajn (1998), pg. 7.

${ }^{8}$ Harrigan (2000), pg. 79.
} 
other factors. ${ }^{9}$ In one such paper, Kaminsky and Reinhart (2000) examine the spread of the Mexican and Asian crises. They use both bilateral and third-country trade linkages (measured by export shares in similar industries) to construct "trade cluster" statistics. Then they use these statistics to estimate how trade affects the conditional probability of an initial crisis spreading to other countries. They find that the bilateral-trade cluster for Latin America is more important than in other regions, but emphasize that all of these trade measures are less influential than financial linkages. They conclude that trade may have played some role in the transmission of the Thai crisis to Malaysia, Korea, and the Philippines, but it "...can certainly not help explain Argentina and Brazil following the Mexican devaluation nor Indonesia following the Thai crisis.." ${ }^{10}$

Van Rijckeghem and Weder (2001) also argue that financial linkages may be more important than trade linkages in explaining country vulnerability to crises. They use BIS data to construct several measures of competition for bank funds during the Mexican, Thai and Russian crises. Then they use these statistics, as well as a series of trade and macroeconomic variables, to estimate the conditional probability of an initial crisis affecting other countries. They find that if either trade linkages or financial linkage are included in the model, the variables are usually highly significant. When both trade and financial linkages are included simultaneously, however, one of the two often becomes insignificant. They conclude that "spillovers through common bank lenders were important in transmitting" these three crises and emphasize that "trade and financial

\footnotetext{
${ }^{9}$ More recently, a number of papers have tested for the relative importance of trade flows, financial linkages, and/or macroeconomic variables in the transmission of recent crises. These papers build on one or more of the approaches outlined in this section. They generally find that trade linkages are important, but overshadowed by other transmission channels. For example, see Caramazza, Ricci and Salgado (2000), De Gregorio and Valdés (2001) or Gelos and Sahay (2000).

${ }^{10}$ Kaminsky and Reinhart (2000), pg. 167.
} 
linkages appear to be highly correlated”, thereby making it difficult to differentiate empirically between these two effects. ${ }^{11}$

Wincoop and Yi (2000) also find mixed support for trade linkages, although they only examine the impact of the Asian crisis on short-run U.S. GDP growth. They argue that the Asian crisis spread to the U.S. through three channels: decreased demand for U.S. exports due to the recession in Asia; exchange-rate movements which reduced the U.S. price of imports from Asia; and capital outflows from Asia which lowered the cost of capital and therefore increased demand in the U.S. They estimate that the significant negative impact on U.S. growth from the first effect was entirely counteracted by the positive impact on U.S. growth from the third effect. (The estimated impact of second effect was minor.) Therefore, Wincoop and Yi suggest that even though the Asian crisis directly affected the U.S. through trade, this effect was entirely offset by other transmission channels.

To summarize, a number of empirical papers have tested for the role of trade in the international transmission of currency crises. The results are as varied as the approaches and techniques utilized. Some papers argue that trade linkages were large and significant; others argue that they were not important, especially in the spread of the Mexican, Asian, and Russian crises. Some of the most recent papers find a small role for trade - although generally overshadowed by other propagation channels. Therefore, this debate on the importance of trade in the international transmission of recent crises can only be resolved through further careful empirical work.

\footnotetext{
${ }^{11}$ Van Rijckeghem and Weder (2001), pg. 12-13
} 


\section{The Theory: Why Might Trade Be Important?}

The theoretical literature modeling exactly how trade can transmit crises is much more limited than the empirical literature testing for its importance. This section begins by briefly summarizing the key theoretical papers on the subject. Then it develops a framework for the empirical analysis in the remainder of the paper. It emphasizes that "trade" incorporates three distinct channels: a competitiveness effect, an income effect, and a cheap-import effect. Since any two of these channels could work in opposite directions, it is necessary to control simultaneously for each of them when analyzing the importance of trade in a country's vulnerability to financial crises.

Gerlach and Smets (1995) is the first paper to model formally how a devaluation in one country can affect trade flows and thereby cause a crisis in another country. In their model, two countries are linked through trade in merchandise and financial assets. A successful attack on one country's exchange rate causes a devaluation and improves the competitiveness of that country's merchandise exports. This produces a trade deficit in the second country and a gradual decline in its central bank's international reserves. This ultimately leads to a speculative attack on the second country's currency. Gerlach and Smets also model a secondary effect of the initial devaluation. This devaluation lowers import prices in the second country, which reduces the aggregate price level and domestic demand. Residents of the country swap domestic currency for foreign exchange, which further depletes the central bank's holdings of international reserves. As a result, the second country could shift to an equilibrium where the central bank does not hold enough reserves to withstand a speculative attack. 
Corsetti, Pesenti, Roubini and Tille (2000) use micro-foundations to develop a more detailed and rigorous model of how trade can transmit crises internationally. They model two channels through which a devaluation in one country can affect other countries. In the first channel, the devaluation lowers the relative price of a country's exports and therefore shifts demand away from countries that produce similar goods. In the second channel, the cheaper exports improve the terms-of-trade for other countries, allowing them to finance a higher level of consumption for any given level of nominal income. Either of these two effects could dominate, so that a devaluation in one country does not necessarily lead to a welfare loss in other countries. In fact, under certain situations the second channel could dominate, and the country that devalues could "beggar-thyself" while simultaneously generating a welfare improvement for other countries.

These theoretical papers explain how trade can transmit crises internationally. ${ }^{12,13}$ A key point from this literature, especially when combined with the empirical review in Section II, is that "trade" incorporates a number of distinct channels. As clearly shown in Corsetti et al. (2000) and Wincoop and Yi (2000), the various channels that constitute trade could counteract each other. As a result, the aggregate impact of trade linkages could be small, even though individual trade channels are large and significant.

\footnotetext{
${ }^{12}$ One additional theoretical paper that deserves note is Paasche (2000). This paper does not focus on trade per se, but shows how a small shock to a country's terms of trade (which could be caused by a devaluation elsewhere in the world or by a reduction in demand for a country's exports) can be magnified by credit constraints and thereby have large domestic consequences. This type of model could be combined with any of the other theoretical models to amplify these trade effects.

${ }^{13}$ Also see Harrigan (2000) and Pesenti and Tille (2000). Harrigan provides a non-technical discussion of the effect of the Asian devaluations on prices and quantities in the U.S. and Asia. Pesenti and Tille discuss the direct impact of bilateral trade flows between countries, as well as the indirect impact of competition in third markets. They provide several numerical examples to show how a devaluation in one country could impact other countries through competition in third markets.
} 
Therefore, any empirical work testing how trade linkages transmit crises should control for each of these channels simultaneously.

The empirical analysis in the remainder of this paper follows this approach. It attempts to simultaneously measure whether these three trade linkages were important determinants of how recent crises impacted other countries. More specifically, it focuses on three trade channels: a competitiveness effect, an income effect, and a cheap-import effect. The "competitiveness effect" is the first channel modeled in Corsetti et al. (2000). This trade effect occurs when one country devalues its currency, reducing the relative price of that country's exports and shifting demand away from goods that compete with those exports. If exports from the crisis country are a large enough share of global production in a given industry, prices in that industry could fall worldwide. Therefore, even if a country does not directly compete with exports from the crisis country in any specific markets, its export competitiveness could be damaged through these global industry effects. ${ }^{14}$

The second trade channel is what this paper calls an "income effect". ${ }^{15}$ This occurs when a crisis affects a country's income level (or even income distribution) and growth rate, which in turn affects that country's demand for imports. Other countries that export directly to the crisis country will experience a shift in demand for their goods. Most of the empirical work discussed in Section II assumes that any income effect is negative, since recent crises have generated a sharp contraction in economic growth and reduction in aggregate demand (within the crisis country). The historical evidence on the

\footnotetext{
${ }^{14}$ There could also be secondary-competitiveness effects if exports from the country which devalued are used as inputs for the production of goods in other countries. In this case, the currency crisis could improve, rather than reduce, the competitiveness of these products.

${ }^{15}$ Wincoop and Yi (2000) call this a domestic demand effect.
} 
impact of currency crises on growth and demand, however, is mixed. ${ }^{16}$ In many cases a currency crisis leads to a devaluation, which improves growth performance and aggregate demand in the crisis country. Therefore, the sign of any income effect is a priori indeterminate.

The final trade channel that this paper examines is a "cheap-import effect". ${ }^{17}$ This occurs when a country devalues its currency, reducing the relative price of its exports and improving the terms-of-trade in other countries. Imports into non-crisis countries are now available at a cheaper price, potentially allowing them to finance a higher level of consumption for any given level of nominal income. This trade linkage could have a positive impact on a country's welfare when a crisis occurs elsewhere in the world.

To summarize, this paper tests if three trade channels (competitiveness, income, and cheap-import effects) are important determinants of a country's vulnerability to recent financial crises. This paper does not test for the importance of other transmission channels, such as common bank lenders, capital flows responding to changes in interest rates, or changes in investor sentiment. Although these other channels are undoubtedly important, and may even interact with trade flows, this paper maintains its narrow focus in order to carefully assess the significance and magnitude of these trade linkages.

\section{The Crisis Events}

In order to test for the role of trade linkages during recent crises, it is necessary to begin by defining exactly when these crises occurred. In many cases, such as the Mexican

\footnotetext{
${ }^{16}$ For example, Gupta et al. (2000) examine the response of output during crises. They find that about 40 percent of crises have been expansionary. Also see Goldstein, Kaminsky, and Reinhart (2000, chapter 7), for a survey of the literature examining how currency crises affect a variety of economic indicators.
} 
peso devaluation in December of 1994, it is not only clear that a crisis occurred, but also fairly straightforward to date when the crisis began. Other cases, however, are much harder to define. For example, in the aftermath of the Mexican devaluation, Argentina raised short-term interest rates to 44 percent (versus about 7 percent immediately before the Mexican crisis) and still suffered a large outflow of reserves. ${ }^{18}$ Does this qualify as a crisis? Or, even though Brazil did not devalue its currency until January of 1999 (an event which most people would agree is a crisis), how should we classify periods such as the week in early September of 1998 when Brazil raised interest rates from about 20 to 40 percent to forestall a devaluation?

These situations suggest that focusing only on exchange-rate movements may miss important periods of pressure on a country's currency. Therefore, I follow a convention frequently used in the currency-crisis literature and construct an "exchangemarket pressure index" which accounts for movements in a country's exchange rate, interest rate, and reserve levels. Although this index is somewhat ad hoc, it does capture the three main defenses a country has against a speculative attack (devalue its currency, raise interest rates, or pay out reserves.) More specifically, I construct a weighted index of exchange-market pressure (EMP) similar to that introduced in Eichengreen, Rose, and Wyplosz (1996):

$$
E M P_{n t}=\alpha \% \Delta e_{n t}+\beta\left[\left(i_{n t}-i_{U t}\right)-\left(i_{n y}-i_{U y}\right)\right]-\gamma\left(\% \Delta r_{n t}-\% \Delta r_{U t}\right)
$$

\footnotetext{
${ }^{17}$ This is also called the "bilateral trade effect" in Corsetti et al. (2000) and the "supply effect" in Wincoop and Yi (2000).

${ }^{18}$ Data sources are discussed below.
} 
where $e_{n t}$ is the nominal exchange rate for country $n$ 's currency in U.S. dollars at time $t$; $i_{n t}$ is the short-term interest rate for country $n$ at time $t ; i_{U t}$ is the short-term interest rate for the U.S. at time $t ; i_{n y}$ and $i_{U y}$ are the same two interest rates calculated as rolling averages for the previous year (starting at date $t-1)^{19}$; and $r_{n t}$ and $r_{U t}$ are the ratios of international reserves to the money supply for country $n$ and the U.S., respectively. Each component of the index is entered so that higher values of the index indicate greater levels of exchange-market pressure. Each component of the index is also weighted by the inverse of the standard deviation for each series (the $\alpha, \beta$, and $\gamma$ ) in order to equalize conditional volatilities and ensure that no single series dominates the index.

In order to focus on recent currency crises (and to correspond with the trade data used in Section V), I calculate this exchange-market pressure index for five years - from July 1, 1994 through June 31, 1999. The data for U.S. dollar exchange rates and shortterm interest rates is compiled on a weekly basis from Datastream. The data on reserves and the money supply (M1) is collected from the International Financial Statistics CDROM published by the International Monetary Fund. This information is only available on a monthly basis, so I interpolate to estimate weekly statistics. Also, I exclude countries with an annual rate of consumer price inflation greater than 100 percent. ${ }^{20}$ Further information on data sources and definitions is available at the beginning of the appendix.

\footnotetext{
${ }^{19}$ This component of the index is generally calculated as a period-to-period change instead of a period-toyear change. I depart from this convention to adjust for the fact that a country may raise interest rates to defend its currency for longer than one period. This is particularly important for this paper's analysis since the time periods $(t)$ are weeks instead of months or quarters.

${ }^{20}$ Adjusting this cutoff to either 50 or 150 percent has minimal impact on the results. I also exclude Luxembourg, Pakistan, Kenya, Russia before 1997, and Sri Lanka because none of these countries has the trade data during this period that is necessary for the analysis in the remainder of the paper.
} 
The resulting sample used to calculate the exchange-market pressure index consists of the 45 countries listed in Table $1 .^{21}$

The final step is to specify the critical value for the EMP index such that index values above this level qualify as a crisis. I use the criteria:

$$
\begin{aligned}
\text { Crisis }_{n, t} & =1 & & \text { if } \mathrm{EMP}_{\mathrm{n}, \mathrm{t}}>\mu_{E M P}+5 \sigma_{E M P} \\
& =0 & & \text { otherwise }
\end{aligned}
$$

where Crisi $_{n t}$ is an indicator variable equal to one if a crisis occurs in country $n$ at time $t$;

$\mu_{E M P}$ is the mean of the EMP index; and $\sigma_{E M P}$ is the standard deviation of the index.

These criteria generate 41 country-week crisis periods. ${ }^{22}$ Many of these one-week crisis

periods, however, are clearly part of a single crisis event. (For example, Mexico has 5

"crises" between December 19, 1994 and March 19, 1995.) Therefore, I include any

crisis-week that occurs within one year of a country's initial crisis as part of a single

crisis event. In other words, a country can have, at most, one crisis per year. This

generates a sample of 16 recent crises that are listed chronologically in Table 1 . The

weeks included in each crisis event are listed in the second column of the table. The average length of a crisis is 2.6 weeks.

\footnotetext{
${ }^{21}$ Since this paper uses weekly data and includes interest rates as one component of the exchange-market pressure index, the sample of countries is smaller than in other papers that calculate a similar crisis index. The shorter time periods are critical, however, to accurately identify the crisis windows, as well as to capture short periods of intense exchange-market pressure. Moreover, the focus of this paper is to measure country vulnerability to these crises, and the sample of countries used for this analysis is larger.

${ }^{22}$ The sensitivity analysis examines the impact of using lower critical values to define the crisis events. As shown in Section VI, this has no significant impact on results. I focus on the stricter definition of a crisis for two reasons. First, a less stringent definition includes many events that are not intuitively "crises." Second, and most important, a less stringent definition identifies a number of weeks as crises that occur simultaneously in different countries. This complicates any empirical analysis of how each crisis impacts other countries.
} 
This list captures most of the recent events that gained attention as major currency crises, as well as a number of less publicized events. For example, the list includes the most obvious crises since mid-1994: the Mexican devaluation in December of 1994; the Thai crisis in July of 1997; the Korean devaluation in December of 1997; the Russian crisis in August of 1998; and the Brazilian devaluation in January of 1999. It also includes some less obvious "crises", such as the exchange-market pressure on Argentina's peso in March of 1995 and on India's rupee in January of 1998. Many of these events do not include a major currency devaluation, but instead reflect a significant rise in interest rates and/or loss in reserves to counter exchange-market pressure. ${ }^{23}$ One interesting pattern in Table 1 is that crises tend to be bunched in time as well as by region. For example, there were several crises in Latin America at the end of 1994 and throughout 1995 . This was followed by a relatively calm period, until the Thai devaluation in 1997 was quickly followed by a series of crises across Asia.

\section{The Model, Data, and Trade Statistics}

Now that the crisis events have been identified, it is possible to estimate if the three trade channels are important determinants of a country's vulnerability to recent crises. For simplicity, I refer to the country experiencing the initial crisis as the groundzero country. ${ }^{24}$ The base model, which is estimated for the sample of 16 crises, is:

$$
\text { Return }_{n, e}=\theta_{1} \text { Compete }_{n, e}+\theta_{2} \text { Income }_{n, e}+\theta_{3} \text { Cheap Import }_{n, e}+\theta_{4} \boldsymbol{X}_{n, e}+\theta_{5} \boldsymbol{P}_{e}+\boldsymbol{\varepsilon}_{n, e}
$$

\footnotetext{
${ }^{23}$ Section VII analyzes how these different types of crises (i.e. largely driven by currency devaluations versus interest rate increases) determine how a crisis affects other countries.
} 
where Return $_{n, e}$ is the stock market return for country $n$ over the crisis event $e$; Compete $_{n, e}$ is a measure of any competitiveness-effect linkages between country $n$ and the groundzero country; Income $_{n, e}$ is a measure of any income-effect linkages between country $n$ and ground-zero country; Cheap Import $_{n, e}$ is a measure of any cheap-import effect linkages between country $n$ and the ground-zero country; $\mathbf{X}_{n, e}$ is a set of macroeconomic control variables for country $n$; and $\mathbf{P}_{e}$ is a set of period dummies (for each crisis event $e$ ). These period dummies are included to control for any global events or aggregate shocks that affect all countries during the crisis. Each of the independent variables is measured during the year prior to the starting date of the crisis. For example, the trade and macroeconomic variables for the Thai crisis (which began in June of 1997) are measured in $1996 .^{25}$ This timing convention is utilized so that the independent variables do not incorporate any impact of the crisis.

This model focuses on stock returns (the dependent variable) to measure a country's vulnerability to a crisis for several reasons. First, stock returns are available for a large sample of countries (even a larger sample than used to calculate the crisis index). Second, since stock returns are measured at a much higher frequency than most macroeconomic and trade variables, stock returns can more accurately pinpoint the effects of a specific crisis. This is particularly important when a series of crises (such as those in Thailand, the Philippines, and Indonesia) are bunched together in time. Third, since stock returns incorporate the immediate impact of a crisis as well as the expected longer-term effects, stock returns should capture the total impact of a crisis on a

\footnotetext{
24 This terminology is borrowed from Glick and Rose (1999).

${ }^{25}$ The one exception is the Mexican crisis (which occurred on various weeks between 12/19/94 and 03/19/95). Due to data limitations for the trade variables, the independent variables are measured in 1994.
} 
particular country. Granted, stock returns also have a number of shortcomings. Any sort of investor behavior that drives markets from their long-term equilibrium could reduce the ability of stock returns to accurately capture the long-term impact of a crisis. ${ }^{26}$ Despite these shortcomings, stock returns are the most accurate indicator available for a large sample of countries at the high frequency necessary to isolate the impact of different crises that occur close together in time.

The data used to measure each of the variables in equation (3) comes from a variety of sources. For the base analysis, stock returns $\left(\operatorname{Return}_{n, e}\right)$ are measured as abnormal weekly stock returns (written as percents) for the market index in country $n$ expressed in U.S. dollars. ${ }^{27}$ The stock index data is from Datastream. For crisis events that last longer than one week, Return $_{n, e}$ is calculated as the average abnormal stock return over each week that qualifies as a crisis (as specified in Table 1). Therefore, for the Mexican crisis which is defined as including 5 weeks between December 19, 1994 and March 19, 1995, Return $_{n, e}$ is calculated as the average, abnormal, weekly stock return over the 5 weeks identified as crisis-events in Table 1 . The macroeconomic variables are taken from the International Financial Statistics $C D-R O M$ published by the International Monetary Fund and the World Development Indicators CD-ROM published by the World Bank. The appendix provides further information on each of these data sources and definitions, including a table of summary statistics.

Since the crisis occurred near year-end, however, there should be minimal feedback on the annualized trade and macroeconomic variables.

${ }^{26}$ For example, Barberis, Shleifer and Vishny (1998) show that markets tend to under-react to individual news and over-react to a long series of related news.

${ }^{27}$ Abnormal stock returns are calculated as stock returns during the crisis period minus average returns (i.e. normal returns) for the one-year preceding the start of the crisis. One week preceding the start of the crisis is excluded from the calculation of normal returns in case there were any unusual market movements directly before the crisis. 
The three trade-linkage variables are calculated using data from the International Trade Centre/UN Statistics Division (1999), which reports bilateral trade flows between most countries in the world by 4-digit SITC codes between 1994 and 1998. The competitiveness variable $\left(\right.$ Compete $\left._{n, e}\right)$ is calculated as a weighted product of two terms. The first term is exports from the ground-zero country in a given industry as a share of global exports in that industry. This term captures how important exports from the crisis country are to the industry, and therefore the potential impact of the crisis on the industry as a whole. The second term is total exports from country $n$ in the same industry, as a share of country $n$ 's GDP. This term captures the importance of each industry to country $n$, and therefore country $n$ 's potential vulnerability to the crisis. Finally, these products are calculated and summed across all four-digit industries for each country-crisis pair and weighted by the maximum calculated value (and multiplied by 100). This creates an index that can take values from 0 to $100 .^{28}$ In other words, the competitiveness variable for country $n$ during crisis event $e$ can be written:

$$
\text { Compete }_{n, e}=\frac{100}{\text { Max }_{\text {Compete }}} \sum_{k}\left(\frac{\operatorname{Exp}_{0, k, W}}{\operatorname{Exp}_{W, k, W}} * \frac{\operatorname{Exp}_{n, k, W}}{G D P_{n}}\right)
$$

where $\operatorname{Exp}_{0, k, W}$ is exports from the ground-zero country in industry $k$ to every other country in the world $(W) ; \operatorname{Exp}_{W, k, W}$ is exports from every country in the world in industry $k$ to every other country in the world; $\operatorname{Exp}_{n, k, W}$ is exports from country $n$ in industry $k$ to every other country in the world; $G D P_{n}$ is gross domestic product for country $n$; and

\footnotetext{
${ }^{28}$ Ideally, this competitiveness indicator would also incorporate the elasticities of substitution between goods from different countries. To the best of my knowledge, however, these statistics do not currently
} 
Max $_{\text {Compete }}$ is the maximum value of the product in parentheses for every country-crisis pair in the sample. All variables are measured in U.S. dollars for the one-year period ending before the start of the crisis event $e$. The $k$ industries are 1075 4-digit SITC groups.

Since Compete is a key variable for this paper's analysis, Tables 2 and 3 provide further information on this index. Table 2 (parts A and B) presents a sample of values for the first ratio in the product in parentheses in equation (4). It lists the 10 largest 4-digit export industries for each ground-zero country (when measured as a share of world exports in each industry). Not surprisingly, smaller countries tend to have a smaller share of global exports in most industries. For example, the most important export industry for the Slovak Republic is flat, cold-rolled producers' iron (SITC group 6734) which comprises only 3.5 percent of global exports in this industry. Larger countries have a larger share of export industries on average, such as Korea that exports 41 percent of the world's exports of fabric made of synthetic-filament yarn (SITC group 6531). On the other hand, several small and medium-sized economies dominate specific export markets, especially for certain agricultural products and natural resources. For example, India exports 82 percent of world exports in castor oil seeds (SITC group 2235); the Philippines exports 58 percent of global exports in coconut oil fractions (SITC group 4223); the Czech Republic exports 51 percent of global exports in lignite (SITC group 3222); and Russia exports 48 percent of global exports in gaseous natural gas (SITC group 3432). Any other country that was highly dependent on export revenues in any of these industries could have been extremely vulnerable to competitiveness effects from crises in these ground-zero countries.

exist. 
Table 3 lists the calculated values of Compete. Parts A and B of the table report values for each of the 58 countries in the sample for each crisis event. Part C lists a number of summary statistics for the entire sample. The values of Compete range from almost 0 to 100, with a mean of 5.0 and standard deviation of 9.3. Larger values of Compete indicate that a country's economy was more dependent on industries that were most affected by the crisis. The highest value of Compete occurs for Singapore during the Korean crisis. Some of the four-digit industries generating this large competitiveness effect are: electronic microcircuits; input or output units; storage units for data processing; color television receivers; sound and video recording; parts for telecommunications equipment; and ships, boats and other vessels. Many of the other large values of Compete occur between countries dependent on natural resources and ground-zero countries that export a large quantity of these resources. For example, some of the larger values of Compete occur for oil-dependent Oman and Norway during the crises in Russia and Venezuela.

It is also worth noting several trends in Compete across crisis events. The average value of Compete fluctuates significantly across episodes and is much lower for crises that occur in small countries. For example, the mean value of Compete is less than 1 for crises that originate in Ecuador and the Slovak Republic, but over 12 for the crisis in Korea. Compete is also smaller for countries that are less integrated with the rest of the world, even after adjusting for country size. For example, the Indian economy is over four times larger than the Indonesian economy (as measured by GDP), but the mean value of Compete for the Indian crisis was less than half that for the Indonesian crisis. Both of these characteristics of Compete suggest that this variable captures the intuitive 
prediction that crises in larger and more export-oriented economies would have greater competitiveness effects on other countries.

The other two trade variables used to estimate equation (3) are more straightforward. The income-effect variable (Income) is measured as total exports from each country $n$ to the ground-zero country as a percent of country $n$ 's GDP. In other words, the income-effect variable for country $n$ during crisis event $e$ can be written:

$$
\text { Income }_{n, e}=\frac{\sum_{k} \operatorname{Exp}_{n, k, 0}}{G D P_{n}} \text {, }
$$

where $\operatorname{Exp}_{n, k, 0}$ is exports from country $n$ in industry $k$ to the ground-zero country; and $G D P_{n}$ is gross domestic product for country $n$. All variables are measured in U.S. dollars for the one-year period ending before the start of the crisis event $e$.

Income captures the impact of the crisis on the demand for exports from other countries. Table 4 presents the calculated values of Income. Parts A and B of the table list the values for each of the countries in the sample, and part $\mathrm{C}$ lists a number of summary statistics. The values of Income range from 0 to 15 percent, with a mean of 0.2 and a standard deviation of 0.8 . Not surprisingly, countries located in the same geographic region as the ground-zero country tend to be more reliant on exports to the crisis-country and therefore be more vulnerable to any income effect. For example, the largest value of Income (15 percent), measures the reliance of the Slovak Republic on exports going to the Czech Republic. The second largest value of Income (12 percent) measures exports from Estonia (as a share of GDP) going to Russia. 
The final trade variable, the cheap-import effect (Cheap Import), is measured as total imports from the ground-zero country into country $n$ as a percent of consumption and investment in country $n \cdot{ }^{29}$ In other words, the cheap-import effect variable for country $n$ during crisis event $e$ can be written:

$$
\text { Cheap Import }_{n, e}=\frac{\sum_{k} \operatorname{Imp}_{n, k, 0}}{\text { Consumption }_{n}+\text { Investment }_{n}},
$$

where $\operatorname{Imp}_{n, k, 0}$ is imports into country $n$ in industry $k$ from the ground-zero country; and Consumption $_{n}$ and Investment $_{n}$ are total private consumption and gross domestic investment, respectively, for country $n$. All variables are measured in U.S. dollars for the one-year period ending before the start of the crisis event $e$.

Cheap Import captures the potential effect of lower import prices in the groundzero country on the other countries in the sample. Table 5 lists the calculated values and summary statistics. Many of the values, including the summary statistics, are similar to those for Income. ${ }^{30}$ Countries located in the same geographic region as the ground-zero country tend to have a higher share of imports from that country and therefore be more vulnerable to any cheap-import effects.

\footnotetext{
${ }^{29}$ The denominator of this ratio includes private consumption and gross domestic investment in order to focus on the portion of GDP which is most affected by lower import prices. Other components of GDP, such as government consumption and net exports, are less affected by changes in import prices.

${ }^{30}$ The correlation between Income and Cheap Import is 87 percent.
} 


\section{Estimation Results and Sensitivity Tests}

Table 6 reports results when these measures of Compete, Income, and Cheap Import are used to estimate the model specified in equation (3). ${ }^{31}$ Column 1 reports results when only the trade variables (and no macroeconomic controls) are included in the model. Columns 2 through 7 add a variety of macroeconomic controls that are frequently used in this literature. Column 6 uses the same control variables as the base specification in Glick and Rose (1999), and column 7 includes all of the control variables simultaneously. Each of the trade variables has the predicted sign in Table 6, although each is not consistently significant across columns. More specifically, the coefficient for the competitiveness effect is always negative and significant at the 1 percent level. The coefficient for the income effect is always negative and significant at the 5 percent level, as long as some macroeconomic controls are included in the specification. The coefficient for the cheap-import effect is always positive, although usually insignificant.

These estimates suggest that not only are the trade effects significant, but their magnitude can be large. Since the point estimates fluctuate across columns, I focus on the estimates in column (2). This specification includes the control variables most frequently cited in the literature, as well as the greatest number of observations (for any specification that includes macroeconomic controls). The point estimate for the competitiveness effect in column 2 is -0.05 . This indicates that if a county's competitiveness index was 10 points higher, its abnormal weekly stock return is predicted to be 0.5 percentage points lower, on average, during each week of the crisis. Moreover, since the average length of a crisis in Table 1 is 2.6 weeks, and the Russian crisis is defined as lasting for 8 weeks, the cumulative impact on a country's stock market index 
could be much greater. A concrete example can help clarify the magnitude of this competitiveness effect. During the Thai crisis, the competitiveness index for Korea was 6.7 and for Malaysia was 40.4. Therefore, during the 1 week of the Thai crisis, the competitiveness effect is correlated with a 0.3 percent decline in the Korean stock market and a 2 percent decline in the Malaysian market (holding everything else constant).

The point estimate for the second trade variable, the income effect, is -1.02 . This implies that if a country's ratio of exports to the crisis country (as a share of GDP) was 1 percentage point higher, its abnormal stock return is predicted to be about 1 percentage point lower, on average, during each week of the crisis. To put these numbers in a more meaningful context, Poland's ratio of exports to Russia during the Russian crisis was 1.5 percent and Finland's ratio was 2.5 percent. Assume that both stock market indices were equal to 100 at the start of the Russian crisis, and that these two countries were otherwise identical. By the end of the 8-week Russian crisis, the income effect predicts a decline in the Polish market of about 12 percent and in the Finn market of about 20 percent. This suggests that small differences in export exposure to a crisis country (such as the 1 percentage point difference between Finland and Poland) can significantly affect a country's vulnerability to a crisis when accumulated over time (an 8 percentage point difference between the two markets).

Potentially counteracting this income effect, however, is the cheap-import effect. The point estimate for the cheap-import effect is 0.59 . This implies that if a country's import penetration ratio was 1 percentage point higher, the country's abnormal stock return is predicted to be 0.59 percentage points higher, on average, during each week of the crisis. To put this in context, during the Brazilian crisis the import penetration ratio

\footnotetext{
${ }^{31}$ The period-dummy variables are not reported but are always jointly significant.
} 
was 1.5 for Chile and 2.6 for Argentina. According to the regression results, after the 1week Brazilian crisis the cheap-import effect is correlated with an increase in the Chilean and Argentine stock market indices of 0.9 and 1.5 percentage points, respectively (again holding everything else constant).

Since these trade variables are highly correlated (especially the income and cheap-import effects), it is more meaningful to examine the combined impact of all three variables rather than focus on one effect in isolation. Table 7 performs this analysis for the countries and crises discussed above. It estimates the model specified in column 2 of Table 6 (excluding the country-crisis pairs used for the relevant out-of-sample predictions) and assumes that the stock market index for each country is 100 directly before the crisis. ${ }^{32}$ Columns 1 through 3 report the predicted weekly impact on each country's stock market index from each of the trade effects. Column 4 combines these into the total aggregate predicted weekly impact from the trade variables, and column 5 reports the total predicted impact of all the other macroeconomic control variables. Column 6 lists the model's predicted abnormal weekly returns (the sum of the predicted trade and macroeconomic effects, as well as the crisis-event dummies), and column 7 reports the actual, abnormal weekly stock market return for each country during the given crisis.

The statistics in this table make a number of key points. First, the magnitude of the trade effects can be large. For example, trade linkages during the Thai crisis were predicted to reduce Malaysia's weekly stock return by 3.6 percentage points. Moreover, for longer crises (such as the 8-week Russian crisis) the cumulative impact of these trade effects can be much larger. Second, the predicted impact of the trade variables tends to be 
larger than the predicted impact of the macroeconomic variables. For example, during the Brazilian crisis the macroeconomic variables predicted virtually no impact on Argentina's stock market index, while the trade variables predicted a decrease of 1.5 percentage points (about one-third of the actual decrease). Third, the simple regression model in equation (3) only has partial success in predicting stock market movements during recent crises. In most of the examples in the table, predicted stock market returns are much lower (in absolute value) than actual returns. This is not surprising given the fairly low $\mathrm{R}^{2 \text { 's }}$ in Table 6. On the other hand, the model does fairly well in explaining stock market returns during crises that have more regional than global effects (such as the Thai and Brazilian crisis), but does not have as much explanatory power for crises that have greater global effects (such as the Russian crisis).

These central results could be influenced by a number of factors such as: sample selection; variable definitions; and model specification. Therefore, this section closes by describing a number of sensitivity tests. Results are highly robust, so Table 8 only reports a selection of these results. ${ }^{33}$ First, I test for the impact of sample selection. I drop one country at a time, one crisis at a time, and the five extreme observations for each variable. Next, since the distribution of Compete is skewed to the right, I drop the five largest values for Compete. Results are reported in column 2 of Table 8 . Then, since Venezuela and Ecuador each have more than one crisis (which could place too much weight on events in these countries), I only include the first crisis-event for each country in the sample. Finally, since many of the extreme values for the competitiveness effect occur in oil-exporting countries during crises in oil-producing regions, I exclude the major oil

\footnotetext{
${ }^{32}$ To simplify this comparison, it also assumes that normal returns for each market are zero.

${ }^{33}$ Full results are obviously available from the author.
} 
exporters from the sample. These results are reported in column 3 of Table 8 . In each of these tests, the coefficients on the competitiveness and income effects are negative and significant. The cheap-import effect is always positive, but its significance fluctuates.

As a second series of sensitivity tests, I examine the effect of using alternate variable definitions. I begin by redefining the income effect as exports from country $n$ to the crisis country as a share of total exports from country $n$ (instead of as a share of country $n$ 's GDP). Then I recalculate the cheap-import effect as imports into country $n$ from the crisis country as a share of total imports into country $n$ (instead of the sum of consumption and investment in country $n$ ). Finally, I use normal returns instead of abnormal returns for the dependent variable. (In other words, I no longer subtract each country's average stock market return for the year preceding the crisis.) The first set of results is reported in column 4 of Table 8. The coefficients for the competitiveness and income effects remain negative and significant in each of these tests.

As a third set of robustness tests, I estimate a number of variations to the base specification. Since there is no reason to believe that the relationship between the trade variables and stock returns is linear, I include logarithmic, squared and/or cubed terms for each of the trade variables. In most cases, the linear model outperforms the extended models, although there is weak evidence that the income effect may decrease at higher values. Next, I add a number of additional control variables, such as: GDP, GDP per capita, an OECD dummy, and an oil-exporter dummy. Then, since different crises are driven by different combinations of currency and interest rate movements (a question investigated in more depth in the next section), I weight each of the trade variables by the 
change in the relevant variable in the ground-zero country. ${ }^{34}$ Finally, since the trade variables (especially the income and cheap-import effects) may be capturing regional effects, I add a series of detailed regional-dummy variables to the base specification. A sample of these results is reported in columns 5 through 7 of Table 8 . In each case, the coefficients for the competitiveness and income effects remain negative and significant. Moreover, it is worth emphasizing the results in the last column that include the regional dummy variables. These regional dummy variables are jointly significant and several are individually significant. Even after controlling for these regional effects, however, the competitiveness and income effects are still negative and highly significant. This suggests that the trade variables are not simply capturing regional effects, such as financial linkages or regional learning.

As a final series of sensitivity tests, I change the definition of a crisis used in equations (1) and (2). More specifically, I use two less stringent criteria for an event to qualify as a crisis. First, I define a crisis as any week for any country in the sample where:

$$
E M P_{n, t}>\mu_{E M P}+3 \sigma_{E M P}
$$

The resulting sample of crisis events is listed in Table 9. There are now 27 crises (versus 16 in the base analysis), lasting an average of 4.0 weeks (versus an average of 2.6 weeks in the base analysis). Second, I redefine a crisis as any week where:

\footnotetext{
${ }^{34}$ More specifically, I weight Compete and Cheap Import by the percent change in the ground-zero country's exchange rate, and I multiply Income by the percent change in the ground-zero country's interest
} 


$$
E M P_{n, t}>\mu_{E M P}+1.5 \sigma_{E M P}
$$

The resulting 57 crisis events are listed in Table 10, with the average crisis lasting 5.3 weeks. Finally, I reestimate the model in equation (3) using these larger samples of crisis events. Results for three different specifications are reported in Table 11. The competitiveness and income effects remain negative and significant in each specification, and the bargain effect remains positive (with fluctuating significance.)

To conclude, this series of sensitivity tests suggests that the competitiveness and income effects are negative, significant, and robust. The cheap-import effect is generally positive, although its significance varies across specifications. These trade effects can be large and economically important determinants of a country's vulnerability to a crisis that originates elsewhere in the world. It is worth emphasizing, however, that this simple model does not explain most of the variation in countries' stock market returns. The $\mathrm{R}^{2 \text {, }} \mathrm{s}$ range from about 0.20 to 0.28 for the various specifications in Tables 6 and 8 , and the trade and macroeconomic variables often under-predict stock market movements in the comparisons in Table 7. Therefore, although trade linkages (and macroeconomic variables) are important, they are clearly not the only factors affecting a country's stock market returns. Other factors, such as financial linkages or changes in investor sentiment may also be important determinants of country's vulnerability to financial crises.

\section{Do Different Types of Crises Generate Different Trade Effects?}

The previous analysis used an exchange-market pressure index, which incorporated changes in exchange rates, interest rates, and reserve levels, to define a

rate spread. Data sources and variable definitions are described in Section IV. 
series of crises from 1994 through 1999. There are, however, significant differences across these crises, especially in the relative importance of each component of the exchange-market pressure index. Many of these crises, such as those in Mexico and Thailand, involved substantial currency devaluations. During other crises, such as in Argentina, the currency's value remained fairly stable and the government responded by raising interest rates and paying international reserves.

Moreover, how a country responds to increased pressure on its exchange rate could determine how the crisis is transmitted to other countries. For example, if a crisis includes a large currency devaluation, then exports from the crisis country will become relatively cheaper on international markets and the crisis could spread through competitiveness and cheap-import effects. On the other hand, if the currency's value remains fixed, there should not be significant competitiveness or cheap-import effects. Similarly, if the crisis includes a large increase in interest rates, this is likely to slow investment and growth in the crisis region. This could lead to a larger income effect than if interest rates were left unchanged and/or decreased.

To test if differences across crises determine how they impact other countries, I divide the sample of crises identified in Table 1 into two subgroups. The first subgroup is any crisis that includes a currency devaluation of 10 percent or more during at least one week of the crisis. The second subgroup is any crisis that includes an increase in the interest rate spread of 30 percent or more during at least one week of the crisis. ${ }^{35}$ The crises that qualify in these subgroups are listed in Table 12. As shown in the table,

\footnotetext{
${ }^{35}$ Both statistics are calculated as described in Section IV. More specifically, the exchange rate is calculated as the nominal U.S. dollar exchange rate. The interest rate is calculated as the short-term interest rate spread (versus the U.S. rate) less the same spread averaged over the previous year.
} 
slightly over half of the crises include a major currency devaluation, and three-quarters of the crises include a major increase in interest rates.

Next, I re-estimate equation 3 for each of these crisis subgroups, using the same methodology, definitions and specification as the base results reported in Section VI. Table 13 reports results. Column 1 repeats estimates for the entire sample of 16 crises. Columns 2 and 3 report results for crises that include and do not include, respectively, a major currency devaluation. Columns 4 and 5 report results for crises that include and did not include, respectively, a major increase in interest rates. Most of the estimates in Table 13 support the predictions discussed above. The competitiveness effect is negative and highly significant during crises that include a major devaluation, but highly insignificant during crises that do not include a major devaluation. The income effect is negative and highly significant during crises that include a major increase in interest rates, but is highly insignificant during crises that do not include a major increase in interest rates. Estimates for the cheap-import effect are generally insignificant and are the only coefficients that do not follow the above predictions. This is not surprising, however, given the general lack of robustness for this coefficient.

These results have an important implication. When a country's exchange rate is under pressure during a crisis, the country's response is a critical determinant of how the local crisis affects the rest of the world. If the country responds by devaluing its currency (or allowing its currency to depreciate), then other countries that compete with the crisis country's exports will be affected by the change in relative export prices. On the other hand, if the country responds by raising interest rates, this will directly affect countries that export to the crisis country, probably through a contraction in income and 
investment. Therefore, how a country responds to a crisis is an important determinant of how that crisis affects other economies.

\section{Summary and Conclusions}

This paper analyzed whether trade linkages were important determinants of a country's vulnerability to currency crises. It began by discussing previous empirical work on this subject in some detail. Most of these papers use aggregate data on bilateral trade flows between countries. Results are mixed. Some papers argue that trade linkages are important determinants of a country's vulnerability to a crisis, while others argue that trade is not important, especially in the transmission of recent currency crises. A serious limitation of this macro-level work is that the trade data is not disaggregated by industry and therefore does not accurately measure competition in third markets. Moreover, many of these papers could suffer from omitted-variables bias since trade flows are highly correlated with other cross-country linkages, such as financial flows, that are extremely difficult to measure.

Next, this paper surveyed several theoretical papers that explain how trade could transmit crises internationally. More specifically, it explained that "trade" incorporates three distinct channels: a competitiveness effect, an income effect, and a cheap-import effect. A competitiveness effect occurs when one country devalues its currency, increasing the relative competitiveness of its exports and hurting the competitiveness of exports from other countries. An income effect occurs when a crisis affects income and growth within the crisis country, thereby affecting (and probably reducing) purchases of imports from abroad. A cheap-import effect occurs when a country devalues its currency, 
reducing the relative price of its exports and thereby reducing prices in countries that import these goods. Although each of these three trade linkages could transmit a crisis internationally, these various effects may not all work in the same direction. For example, the income effect could partially counteract the cheap-import effect. Therefore, when measuring the importance of trade linkages, it is necessary to isolate each of these effects and measure them independently.

This was the paper's main goal. It attempted to measure the significance and magnitude of each of these three trade linkages in countries' vulnerability to recent crises. To do this, it used trade flow data between most countries in the world, disaggregated at the 4-digit industry level. By utilizing industry-level data, the paper was able to measure competition in third markets more accurately than past work on this subject. In order to perform this analysis, the paper constructed a number of statistics measuring the importance of trade linkages during the 16 most severe crises between 1994 and 1999. The most interesting statistic was the competitiveness variable, which measured the importance of the crisis country to each export industry as well as how dependent other countries were on those industries.

Estimation results suggested that trade linkages were highly significant determinants of a country's vulnerability to recent crises. Countries that competed in the same industries as major exports from the crisis country had significantly lower stock market returns during these crises. Countries that had a larger share of exports going to the crisis countries also had significantly lower stock returns. These competitiveness and income effects both remained highly significant and economically important across an extensive series of sensitivity tests, including less stringent definitions of what constitutes 
a "crisis". Estimates of the third trade effect, the cheap-import effect, usually had the expected sign, but its significance fluctuated across these sensitivity tests. Countries that had a larger share of imports from the crisis country had slightly higher stock returns during these events. Taken as a whole, these results suggest that trade linkages were highly significant determinants of a country's abnormal stock returns during recent currency crises.

Another series of results from this empirical analysis concerned the magnitude and relative importance of trade and other macroeconomic variables in explaining different countries' vulnerability to financial crises. Although trade and macroeconomic variables were significant and economically important, these variables only explain a portion of stock market movements. For example, in the base regression results, trade and macroeconomic variables explained about one-quarter of the variation in countries' abnormal stock returns during recent crises. Three-quarters of the variation is therefore not explained in this simple model. This suggests that other factors, such as financial linkages and investor behavior, may also be important. Estimates also suggested that the impact of trade linkages was greater in magnitude than that of a country's macroeconomic characteristics.

A final empirical result is that the importance of these trade linkages depends on how the crisis country responded to pressure on its exchange rate. When a country responded by devaluing its currency (or allowing it to depreciate), the competitiveness effect was negative and highly significant. When the country maintained a relatively stable exchange rate, there was no significant competitiveness effect. On the other hand, when a country responded to exchange-market pressure by raising interest rates 
substantially, the income effect was negative and highly significant. If the country kept interest rates fairly steady (or only raised them by a small amount), there was no significant income effect. Therefore, how a country responded to a pressure on its exchange rate was a significant determinant of how the crisis affects other countries, and in particular, which trade linkages were important.

This series of results has important implications for the role of international institutions in responding to future financial crises. Real linkages between countries, such as trade, are important determinants of how a crisis spreads internationally. Multilateral assistance and/or bailout packages will have limited success in reducing these crosscountry linkages. On a more positive note, however, multilateral institutions could provide a crisis country with a wider variety of options (with respect to exchange-rate and interest-rate policy) than otherwise available. Therefore, even though multilateral institutions could not prevent the inevitable transmission of a crisis through these trade linkages, they might influence how the country responds to any exchange-market pressure and therefore influence which countries are most affected by the crisis. 


\section{Appendix \\ Data Sources and Definitions}

\section{Data to Calculate the Exchange-Market Pressure Index}

a) Nominal Exchange Rates: Exchange rates expressed as the local currency per U.S. dollar as reported by Datastream.

b) Short-Term Interest Rates: Short-term interest rates as reported by Datastream. The short-term rate is measured by the interbank rate (preferred) or the call rate. If neither of these is available, then the shortest-term rate available is used. The U.S. interest rate is the Federal Fund's rate.

c) International Reserves to the Money Supply: The ratio of total international reserves less gold divided by narrow money (M1). Reserve data is line 1L.dzf and M1 data is line 34..zf from the International Financial Statistics. Weekly data is interpolated from the monthly data.

d) Inflation: Annual percentage change in consumer prices. Data is from line 64.xzf from the International Financial Statistics.

\section{Data to Calculate the Trade-Effect Regressions}

a) Stock Market Returns: Based on stock market indices in U.S. dollars as reported by Datastream. Abnormal returns are calculated as the weekly stock return during the given time period minus the average weekly return (i.e. normal return) for the previous year. Calculation of the normal return excludes one week prior to the start date for the calculation of the abnormal return, in order to exclude any unusual market movements directly before a crisis.

b) Competitiveness Effect: The weighted product of two terms: exports from the ground-zero country in a given industry as a share of global exports in that industry; and total exports from country $n$ in the same industry, as a share of 
country $n$ 's GDP. These products are summed across industries for each countrycrisis pair and weighted by the maximum calculated value (and multiplied by 100). This creates an index that can take values from 0 to 100. All trade data is in U.S. dollars and is reported by the International Trade Centre/UN Statistics Division (1999).

c) Income Effect: Calculated as the ratio of total exports to the ground-zero country to GDP. Export data is from the International Trade Centre/UN Statistics Division (1999). GDP is reported in the World Development Indicators.

d) Cheap-import Effect: Calculated as the ratio of total imports from the ground-zero country to the sum of private consumption and gross domestic investment. Private consumption is the market value of all goods and services, including durable products purchased or received as income in kind by households, but excluding purchases of dwellings. Gross domestic investment consists of outlays on additions to the fixed assets of the economy, plus net changes in the level of inventories. Import data is from the International Trade Centre/UN Statistics Division (1999). Statistics in the denominator are reported in the World Development Indicators.

e) Private Credit Growth: Average annual growth in credit to the private sector. This excludes credit to governments and public enterprises. Data from line 32d..zf of the International Financial Statistics.

f) Government Consumption / GDP: The ratio of general government consumption to GDP as reported in the World Development Indicators. General government consumption includes all current spending for purchases of goods and services (including wages and salaries). It also includes most expenditures on national defense and security, but excludes government military expenditures that are part of government capital formation. 
g) Current Account Surplus / GDP: The current account balance as a percent of GDP, where a positive value indicates a surplus. Data from the World Development Indicators.

h) Bank Reserves / Assets: The ratio of domestic currency holdings and deposits with the monetary authorities to claims on other governments, non-financial public enterprises, the private sector, and other banking institutions. Reported in the World Development Indicators.

i) Private Capital Inflows / GDP: The ratio of gross private capital flows to GDP as reported in the World Development Indicators. Gross private capital flows are the sum of the absolute values of direct, portfolio, and other investment inflows and outflows recorded in the balance of payments financial account, excluding changes in the assets and liabilities of monetary authorities and general government. The indicator is calculated as a ratio to GDP converted to international dollars using purchasing power parities.

j) Domestic Credit Growth: Average annual growth in domestic credit. Data from line 32..zf of the International Financial Statistics.

k) Government Surplus / GDP: The government budget surplus as a percent of GDP, where a positive value indicates a surplus. The government budget surplus is taken from line 80 of the International Financial Statistics and GDP data is taken from the World Development Indicators.

1) Money Supply / Reserves: The ratio of money and quasi money (M2) to gross international reserves as reported in the World Development Indicators. Money and quasi money is the sum of currency outside banks, demand deposits other than those of the central government, and the time, savings, and foreign currency deposits of resident sectors other than the central government (which corresponds to the sum of lines 34 and 35 of the International Financial Statistics). Gross 
international reserves are holdings of monetary gold, special drawing rights, reserves of IMF members held by the IMF, and holdings of foreign exchange under the control of the monetary authorities.

m) Openness: The ratio of total trade to GDP. Total trade is calculated as the sum of all imports and exports as reported by the International Trade Centre/UN Statistics Division (1999). GDP is reported in the World Development Indicators.

n) Growth in GNP per capita: Average annual growth in GNP per capita. Data taken from the World Development Indicators.

o) Inflation: Domestic CPI inflation as reported in line 64 of the International Financial Statistics. 


\section{References}

Baig, Taimur and Ilan Goldfajn. 1998. "Financial Market Contagion in the Asian Crisis." International Monetary Fund Working Paper No. WP/98/155.

Barberis, Nicholas, Andrei Shleifer, and Robert Vishny. 1998. "A Model of Investor Sentiment." Journal of Financial Economics 49: 307-343.

Caramazza, Francesco, Luca Ricci, and Ranil Salgado. 2000. "Trade and Financial Contagion in Currency Crises." International Monetary Fund Working Paper No. $\mathrm{WP} / 00 / 55$.

Corsetti, Giancarlo, Paolo Pesenti, Nouriel Roubini, and Cédric Tille. 2000. "Competitive Devaluations: Toward a Welfare-Based Approach." Journal of International Economics 51: 217-241.

De Gregorio, José and Rodrigo Valdés. 2001. "Crisis Transmission: Evidence from the Debt, Tequila, and Asian Flu Crises." In Stijn Claessens and Kristin Forbes, eds. International Financial Contagion. Boston, MA: Kluwer Academic Publishers, forthcoming.

Eichengreen, Barry and Andrew Rose. 1999. "Contagious Currency Crises: Channels of Conveyance." In Takatoshi Ito and Anne Krueger, eds. Changes in Exchange Rates in Rapidly Developing Countries: Theory, Practice, and Policy Issues. Chicago: University of Chicago Press, pp. 29-50.

Eichengreen, Barry, Andrew Rose, and Charles Wyplosz. 1996. "Contagious Currency Crises." NBER Working Paper No. 5681.

Forbes, Kristin. 2000. "The Asian Flu and Russian Virus: Firm-Level Evidence on How Crises are Transmitted Internationally." NBER Working Paper No. 7807.

Gelos, Gaston and Ratna Sahay. 2001. "Financial Market Spillovers: How Different are the Transition Economies?" In Stijn Claessens and Kristin Forbes, eds. International Financial Contagion. Boston, MA: Kluwer Academic Publishers, pp. 329-366.

Gerlach, Stefan and Frank Smets. 1995. "Contagious Speculative Attacks." European Journal of Political Economy 11: 45-63.

Glick, Reuven and Andrew Rose. 1999. "Contagion and Trade: Why Are Currency Crises Regional?" Journal of International Money and Finance 18: 603-617.

Goldstein, Morris, Graciela Kaminsky and Carmen Reinhart. 2000. Assessing Financial Vulnerability: An Early Warning System for Emerging Markets. Washington, D.C.: Institute for International Economics. 
Gupta, Poonam, Deepak Mishra, and Ratna Sahay. 2000. "Output Response During Currency Crises." International Monetary Fund, mimeo.

Harrigan, James. 2000. "The Impact of the Asia Crisis on U.S. Industry: An Almost-Free Lunch?" Federal Reserve Bank of New York Economic Policy Review 6(3): 71-79.

International Monetary Fund. 2000. International Financial Statistics. Database on CDROM, June.

International Trade Centre / UN Statistics Division. 1999. Trade Analysis System for Personal Computers. Database on CD-ROM.

Kaminsky, Graciela and Carmen Reinhart. 2000. "On Crises, Contagion, and Confusion." Journal of International Economics 51: 145-168.

Masson, Paul. 1998. "Contagion: Monsoonal Effects, Spillovers, and Jumps Between Multiple Equilibria." International Monetary Fund Working Paper No. WP/98/142.

Paasche, Bernhard. 2000. "Credit Constraints and International Financial Crises." Carnegie Mellon University, mimeo.

Pesenti, Paolo and Cédric Tille. 2000. "The Economics of Currency Crises and Contagion: An Introduction." Federal Reserve Bank of New York Economic Policy Review 6(3): 3-16.

Van Rijckeghem, Caroline and Beatrice Weder. 2001. "Sources of Contagion: Is it Finance or Trade?" Journal of International Economics. Forthcoming.

Wincoop, Eric van and Kei-Mu Yi. 2000. "Asia Crisis Post-Mortem: Where Did the Money Go and did the United States Benefit?" Federal Reserve Bank of New York Economic Policy Review 6(3): 51-70.

World Bank. 2000. World Development Indicators. Database on CD-ROM. 


\section{Table 1 \\ The Crisis Events ${ }^{\mathrm{a}}$}

\begin{tabular}{cc}
\hline Country & Crisis Dates \\
\cline { 2 - 2 } Mexico & $12 / 19 / 94-12 / 25 / 94 ; 01 / 16 / 95-01 / 29 / 95 ; 02 / 27 / 95-03 / 05 / 95 ; 03 / 13 / 95-03 / 19 / 95$ \\
Ecuador (1) & $01 / 23 / 95-02 / 12 / 95 ; 10 / 30 / 95-11 / 05 / 95$ \\
Argentina & $03 / 06 / 95-03 / 12 / 95$ \\
Venezuela (1) & $12 / 11 / 95-12 / 17 / 95 ; 04 / 15 / 96-04 / 21 / 96$ \\
Venezuela (2) & $05 / 12 / 97-05 / 18 / 97$ \\
Czech Republic & $05 / 19 / 97-05 / 25 / 97$ \\
Thailand & $06 / 30 / 97-07 / 06 / 97$ \\
Philippines & $07 / 07 / 97-07 / 13 / 97 ; 09 / 29 / 97-10 / 05 / 97$ \\
Indonesia & $012 / 29 / 97-01 / 04 / 98$ \\
& $08 / 11 / 97-08 / 17 / 97 ; 08 / 25 / 97-08 / 31 / 97 ; 09 / 29 / 97-10 / 05 / 97 ; 12 / 08 / 97-12 / 14 / 97 ;$ \\
Korea & $01 / 19 / 98-01 / 25 / 98 ; 03 / 02 / 98-03 / 08 / 98 ; 05 / 18 / 98-05 / 24 / 98$ \\
India & $01 / 19 / 98-01 / 25 / 98$ \\
Russia & $05 / 18 / 98-05 / 31 / 98 ; 07 / 06 / 98-07 / 12 / 98 ; 08 / 10 / 98-09 / 06 / 98 ; 09 / 14 / 98-09 / 20 / 98$ \\
Venezuela (3) & $06 / 15 / 98-06 / 21 / 98 ; 09 / 14 / 98-09 / 20 / 98$ \\
Slovak Republic & $09 / 28 / 98-10 / 04 / 98$ \\
Ecuador (2) & $019 / 98-10 / 25 / 98 ; 1 / 11 / 99-1 / 17 / 99 ; 03 / 01 / 99-03 / 07 / 99$ \\
Brazil & $01 / 17 / 99$ \\
\hline & 0
\end{tabular}

NOTE: (a) Crises defined as weeks when $E M P_{n, t}>\mu_{E M P}+5 \sigma_{E M P}$. Countries included in the sample to test if they experienced a crisis between 07/01/94 and 06/31/99 are: Argentina, Australia, Austria, Belgium, Brazil, Canada, Chile, Colombia, Czech Republic, Denmark, Ecuador, Finland, France, Germany, Greece, Hong Kong, Hungary, India, Indonesia, Ireland, Israel, Italy, Japan, Korea, Malaysia, Mexico, Morocco, Netherlands, New Zealand, Norway, Peru, Philippines, Poland, Portugal, Russia (after 1996), Singapore, Slovak Republic, South Africa, Spain, Sweden, Switzerland, Thailand, the U.K., and Venezuela. The U.S. is included in the sample but cannot experience a crisis due to how the index is defined. 
Table 2: Part A

Major Exports from the Crisis Countries

\begin{tabular}{|c|c|c|c|c|c|}
\hline $\begin{array}{l}\text { SITC } \\
\text { Code } \\
\end{array}$ & SITC Definition & $\begin{array}{c}\text { \% World } \\
\text { Exports } \\
\end{array}$ & $\begin{array}{l}\text { SITC } \\
\text { Code } \\
\end{array}$ & SITC Definition & $\begin{array}{c}\% \text { World } \\
\text { Exports }\end{array}$ \\
\hline \multicolumn{3}{|c|}{ Mexico: 1994} & \multicolumn{3}{|c|}{ Czech Republic: 1997} \\
\hline 7511 & Typewriters, word-processing machines & $24.9 \%$ & 3222 & Lignite & $50.6 \%$ \\
\hline 2667 & Synthetic staple fiber, spinning & 20.0 & 6576 & Hat-shapes, forms, bodies & 13.1 \\
\hline 2832 & Copper mattes, etc. & 19.6 & 2784 & Asbestos & 9.5 \\
\hline 2313 & Other natural gums & 19.6 & 6999 & Articles tungsten, etc. nes & 8.4 \\
\hline 0544 & Tomatoes, fresh, chilled & 16.4 & 2516 & Chemical wood pulp, sulphite & 8.3 \\
\hline 7474 & Safety, relief valves & 15.7 & 2237 & Oil seeds, etc. nes & 7.7 \\
\hline 7731 & Insulted wire, etc. conductors & 14.9 & 6659 & Glass articles, nes & 7.6 \\
\hline 7611 & Color television receivers & 14.7 & 5811 & Artificial sausage casings & 7.1 \\
\hline 2483 & Wood, coniferous, worked, shaped & 14.3 & 3250 & Coke, semi-coke, ret. carbon & 6.9 \\
\hline 6973 & Dom. cooking, heat. appliance, non-electric & 11.3 & 8913 & Non-military arms & 6.5 \\
\hline \multicolumn{3}{|c|}{ Ecuador: 1995} & \multicolumn{3}{|c|}{ Thailand: 1997} \\
\hline 2655 & Abaca, manila hemp, waste & $34.1 \%$ & 2311 & Natural rubber latex & $47.2 \%$ \\
\hline 0573 & Bananas, fresh or dried & 22.5 & 0548 & Vegetable products, roots, tubers & 38.2 \\
\hline 6576 & Hat-shapes, forms, bodies & 12.8 & 0423 & Rice, milled, semi-milled & 37.8 \\
\hline 0721 & Cocoa beans & 9.8 & 2312 & Natural rubber exc. latex & 36.5 \\
\hline 0361 & Crustaceans, frozen & 6.3 & 6129 & Other leather articles, nes & 27.5 \\
\hline 0593 & Juice, other citrus fruit & 5.0 & 0372 & Crustacea, mollusk, prepared nes & 27.4 \\
\hline 0723 & Cocoa paste & 4.7 & 6673 & Precious, semiprecious stones & 23.6 \\
\hline 0711 & Coffee, not roasted & 4.3 & 0471 & Other cereal flours & 22.4 \\
\hline 0713 & Extracts, etc. of coffee & 2.6 & 0621 & Fruit, etc. preserved by sugar & 20.7 \\
\hline 0371 & Fish, prepared, preserved, nes & 2.4 & 2732 & Gypsum, limestone etc. & 20.1 \\
\hline \multicolumn{3}{|c|}{ Argentina: 1995} & \multicolumn{3}{|c|}{ Philippines: 1997} \\
\hline 4215 & Sunflower seed oil, etc. & $35.5 \%$ & 2655 & Abaca, manila hemp, waste & $58.4 \%$ \\
\hline 4211 & Soya bean oil, fractions & 27.6 & 4223 & Coconut oil, fractions & 58.3 \\
\hline 2224 & Sunflower seeds & 24.9 & 2231 & Copra & 15.9 \\
\hline 0176 & Bovine meat, prepared, preserved, nes & 23.3 & 2657 & Coconut fibre and waste & 14.9 \\
\hline 4213 & Groundnut oil, fractions & 22.4 & 2841 & Nickel ores, concentrates & 12.9 \\
\hline 0124 & Meat of horses, mules, etc & 18.6 & 2891 & Precious metal ore, concentrates & 12.8 \\
\hline 0813 & Oil-cake, oilseed residue & 18.4 & 8451 & Babies' garments, cloths acc. & 8.9 \\
\hline 0616 & Natural honey & 17.1 & 8437 & Shirts, mens, boys, knit & 8.3 \\
\hline 0171 & Extract, juice meat, fish & 17.1 & 8944 & Festive articles etc., nes & 7.3 \\
\hline 4212 & Cotton seed oil, fraction & 16.8 & 3442 & Gas hydrocarbon, liquid, nes & 6.7 \\
\hline \multicolumn{3}{|c|}{ Venezuela: 1995} & \multicolumn{3}{|c|}{ Indonesia: 1997} \\
\hline 6724 & Ingots of iron or steel & $17.0 \%$ & 6343 & Plywood, solely of wood & $44.8 \%$ \\
\hline 6713 & Pellets, etc. pig iron, etc & 12.8 & 3431 & Natural gas, liquefied & 44.8 \\
\hline 2239 & Flour, meal, from oilseeds & 11.8 & 4224 & Palm kernel oil, fractions & 44.3 \\
\hline 6932 & Barbed wire, etc. iron, steel & 9.4 & 0721 & Cocoa beans & 35.4 \\
\hline 3330 & Crude petroleum & 8.1 & 2831 & Copper ores, concentrates & 32.0 \\
\hline 5984 & Mixed alkyl benzenes etc., nes & 5.3 & 2312 & Natural rubber exc. latex & 31.6 \\
\hline 6841 & Aluminum, aluminum alloy, unwrought & 4.8 & 4223 & Coconut oil, fractions & 27.2 \\
\hline 4218 & Sesame oil, fractions & 4.7 & 8512 & Sports footwear & 26.9 \\
\hline 0471 & Other cereal flours & 4.4 & 6344 & Other plywood, veneered panels & 24.4 \\
\hline 6733 & Flat, cold-rolled, production iron & 3.7 & 6871 & Tin, tin alloys, unwrought & 20.2 \\
\hline
\end{tabular}


Table 2: Part B

Major Exports from the Crisis Countries

\begin{tabular}{|c|c|c|c|c|c|}
\hline $\begin{array}{l}\text { SITC } \\
\text { Code } \\
\end{array}$ & SITC Definition & $\begin{array}{c}\text { \% World } \\
\text { Exports } \\
\end{array}$ & $\begin{array}{l}\text { SITC } \\
\text { Code } \\
\end{array}$ & SITC Definition & $\begin{array}{c}\text { \% World } \\
\text { Exports } \\
\end{array}$ \\
\hline \multicolumn{3}{|c|}{ Korea: 1997} & \multicolumn{3}{|c|}{ Slovak Republic: 1998} \\
\hline 6531 & Fabric, synthetic filament yarn & $40.8 \%$ & 6734 & Flat, cold-rolled, producers iron & $3.5 \%$ \\
\hline 6118 & Leather, special finish & 32.1 & 6714 & Ferro-manganese & 3.3 \\
\hline 6562 & Labels, badge etc. not embroidered & 29.3 & 2112 & Whole bovine hide $<8 \mathrm{~kg}$ dry & 3.1 \\
\hline 7917 & Rail, tram, coach, etc. nes & 27.1 & 7468 & Other ball, roller bearing & 2.9 \\
\hline 8831 & Cine film, $35 \mathrm{~mm}+$, developed & 26.6 & 7918 & Rail, tram freight cars etc & 2.9 \\
\hline 6132 & Heads, tails, paws etc. & 25.6 & 6611 & Quicklime etc., excluding 522.6 & 2.8 \\
\hline 7932 & Ships, boats, other vessels & 23.8 & 8731 & Gas, liquid, electric meters & 2.3 \\
\hline 7863 & Transport containers & 23.0 & 6715 & Other ferro-alloys & 2.1 \\
\hline 6551 & Pile fabric, knit, crochet & 23.0 & 7912 & Other locomotives, tenders & 2.1 \\
\hline 6965 & Other articles of cutlery & 22.7 & 6732 & Flat, hot-rolled, producers iron & 1.9 \\
\hline \multicolumn{3}{|c|}{ India: 1998} & \multicolumn{3}{|c|}{ Brazil: 1999} \\
\hline 2235 & Castor oil seeds & $81.9 \%$ & 2654 & Sisal, agave fibres, waste & $78.2 \%$ \\
\hline 4225 & Castor oil, fractions & 80.3 & 2851 & Aluminum ore, concentrate & 55.8 \\
\hline 6121 & Leather belting etc. & 56.6 & 4314 & Waxes, animal, vegetable origin & 48.3 \\
\hline 6116 & Goat or kid skin leather & 36.5 & 0611 & Sugars, beet or cane, raw & 39.6 \\
\hline 6545 & Fabric, woven jute, other textile & 34.1 & 0591 & Orange juice & 39.5 \\
\hline 0741 & Tea & 31.0 & 2815 & Iron ore, concentrate, not agg. & 39.1 \\
\hline 2922 & Natural gums, resins, etc. & 29.9 & 4225 & Castor oil, fractions & 38.0 \\
\hline 2225 & Sesame (sesamum) seeds & 27.4 & 2816 & Iron ore agglomerates & 33.5 \\
\hline 6585 & Curtains, other furnishings & 26.9 & 0176 & Bovine meat, prepared, preserved, nes & 29.5 \\
\hline \multirow[t]{2}{*}{6513} & Cotton yarn, excl. thread & 25.6 & 6712 & Pig iron, etc. primary form & 28.4 \\
\hline & \multicolumn{2}{|l|}{ Russia: 1998} & & & \\
\hline 3432 & Natural gas, gaseous & $47.9 \%$ & & & \\
\hline 6727 & Semi-finished iron, etc., $25 \%+c$ & 40.0 & & & \\
\hline 6831 & Nickel, nickel alloy, unwrought & 36.4 & & & \\
\hline 7187 & Nuclear reactors, parts nes & 29.8 & & & \\
\hline 2723 & Natural calcium phosphates & 23.2 & & & \\
\hline 2224 & Sunflower seeds & 22.5 & & & \\
\hline 6726 & Semi-finished iron, steel & 21.8 & & & \\
\hline 2481 & Railway, tramway sleepers & 20.7 & & & \\
\hline 2474 & Wood, coniferous, rough, untreated & 20.1 & & & \\
\hline 6841 & Aluminum, aluminum alloy, unwrought & 19.9 & & & \\
\hline
\end{tabular}


Table 3A: Competitiveness-Effect Statistics

\begin{tabular}{|c|c|c|c|c|c|c|c|c|c|c|c|c|c|c|c|c|}
\hline \multirow[b]{2}{*}{ Country $n$} & \multicolumn{16}{|c|}{ CRISIS EVENTS } \\
\hline & $\begin{array}{c}\text { Mexico } \\
1994\end{array}$ & $\begin{array}{c}\text { Ecuad. } \\
1995\end{array}$ & $\begin{array}{c}\text { Argent. } \\
1995\end{array}$ & $\begin{array}{c}\text { Venez. } \\
1995\end{array}$ & $\begin{array}{c}\text { Venez. } \\
1997\end{array}$ & $\begin{array}{c}\text { Czech } \\
1997\end{array}$ & $\begin{array}{c}\text { Thail. } \\
1997\end{array}$ & $\begin{array}{c}\text { Philip. } \\
1997\end{array}$ & $\begin{array}{c}\text { Indon. } \\
1997\end{array}$ & $\begin{array}{c}\text { Korea } \\
1997\end{array}$ & $\begin{array}{c}\text { India } \\
1998\end{array}$ & $\begin{array}{c}\text { Russia } \\
1998\end{array}$ & $\begin{array}{c}\text { Venez. } \\
1998\end{array}$ & $\begin{array}{c}\text { Slovak } \\
1998\end{array}$ & $\begin{array}{c}\text { Ecuad. } \\
1998\end{array}$ & $\begin{array}{c}\text { Brazil } \\
1999\end{array}$ \\
\hline Argentina & 1.69 & 0.21 & & 0.84 & 1.49 & 0.52 & 1.61 & 0.34 & 1.48 & 2.35 & 2.63 & 3.25 & 1.77 & 0.27 & 0.35 & 7.67 \\
\hline Australia & 2.43 & 0.31 & 2.44 & 2.06 & 1.52 & 1.30 & 2.88 & 0.72 & 6.29 & 6.28 & 2.67 & 7.41 & 2.03 & 0.39 & 0.35 & 8.34 \\
\hline Austria & 8.23 & 0.11 & 1.14 & 0.45 & 0.41 & 3.56 & 4.29 & 1.41 & 3.47 & 11.20 & 2.63 & 8.11 & 0.46 & 1.25 & 0.13 & 4.80 \\
\hline Bangladesh & 1.71 & 0.89 & 0.98 & 0.08 & 0.11 & 0.93 & 6.26 & 1.90 & 5.97 & 5.14 & 9.18 & 0.95 & 0.14 & 0.46 & 1.28 & 1.31 \\
\hline Belgium & 15.26 & 0.79 & 3.39 & 1.41 & 1.37 & 5.99 & 11.19 & 2.39 & 7.32 & 28.50 & 19.46 & 17.85 & 1.66 & 3.10 & 2.14 & 13.88 \\
\hline Brazil & 2.06 & 0.50 & 3.46 & 0.63 & 0.45 & 0.55 & 1.37 & 0.36 & 1.47 & 2.17 & 1.96 & 2.65 & 0.40 & 0.28 & 0.13 & . \\
\hline Canada & 9.11 & 0.47 & 2.14 & 2.73 & 3.04 & 3.30 & 3.88 & 1.92 & 5.89 & 12.76 & 1.87 & 26.29 & 3.87 & 1.37 & 0.65 & 8.75 \\
\hline Chile & 7.48 & 0.34 & 2.29 & 0.53 & 0.31 & 0.99 & 3.68 & 4.79 & 19.37 & 6.34 & 1.78 & 15.54 & 0.37 & 0.41 & 0.44 & 4.72 \\
\hline China & 7.46 & 0.33 & 2.03 & 0.87 & 0.82 & 2.14 & 8.24 & 2.59 & 6.29 & 11.80 & 5.49 & 3.97 & 0.99 & 0.69 & 0.31 & 3.16 \\
\hline Colombia & 5.38 & 5.44 & 0.66 & 2.45 & 4.39 & 0.82 & 3.34 & 1.11 & 6.36 & 2.86 & 2.73 & 6.97 & 5.02 & 0.25 & 4.04 & 13.13 \\
\hline Croatia & 7.24 & 0.33 & 2.17 & 0.66 & 0.67 & 2.79 & 5.36 & 2.11 & 5.01 & 17.71 & 3.68 & 4.15 & 1.06 & 1.32 & 0.40 & 4.44 \\
\hline Cyprus & 1.36 & 0.04 & 1.55 & 0.17 & 0.18 & 0.53 & 1.45 & 0.50 & 1.09 & 1.02 & 1.34 & 0.46 & 0.25 & 0.25 & 0.05 & 0.85 \\
\hline Czech Rep. & 9.05 & 0.18 & 2.04 & 1.35 & 1.18 & . & 6.96 & 1.79 & 6.10 & 16.55 & 4.99 & 10.80 & 1.32 & 2.41 & 0.20 & 9.25 \\
\hline Denmark & 5.40 & 0.52 & 1.72 & 0.67 & 0.90 & 2.33 & 5.93 & 1.28 & 3.78 & 8.90 & 3.17 & 7.11 & 1.49 & 0.89 & 0.75 & 3.98 \\
\hline Ecuador & 17.01 & . & 3.33 & 12.52 & 13.73 & 0.57 & 18.10 & 9.45 & 21.30 & 5.29 & 10.11 & 20.17 & 16.99 & 0.24 & . & 5.41 \\
\hline Egypt & 2.88 & 0.56 & 1.06 & 2.62 & 2.14 & 0.42 & 2.01 & 0.23 & 2.94 & 0.91 & 3.38 & 3.44 & 2.12 & 0.15 & 0.29 & 0.62 \\
\hline Estonia & . & . & . & . & 0.99 & 7.67 & 14.60 & 4.33 & 18.19 & 17.36 & 9.21 & 20.89 & 1.88 & 2.94 & 4.68 & . \\
\hline Finland & 6.78 & 0.35 & 0.76 & 0.45 & 0.42 & 3.02 & 3.62 & 1.67 & 8.12 & 17.95 & 1.56 & 7.79 & 0.52 & 1.59 & 0.10 & 6.37 \\
\hline France & 4.71 & 0.12 & 1.89 & 0.35 & 0.32 & 1.84 & 3.05 & 1.04 & 1.76 & 8.29 & 1.79 & 3.81 & 0.36 & 0.74 & 0.17 & 3.56 \\
\hline Germany & 5.79 & 0.09 & 0.99 & 0.38 & 0.37 & 2.27 & 3.02 & 0.98 & 1.70 & 10.15 & 2.09 & 4.47 & 0.45 & 0.94 & 0.12 & 3.92 \\
\hline Greece & 2.14 & 0.26 & 1.10 & 0.39 & 0.46 & 0.78 & 2.55 & 0.88 & 2.23 & 3.46 & 3.39 & 1.66 & 0.50 & 0.39 & 0.16 & 2.00 \\
\hline Hong Kong & 5.95 & 0.07 & 0.70 & 0.17 & 0.15 & 1.36 & 7.24 & 4.28 & 4.24 & 12.88 & 4.58 & 1.40 & 0.13 & 0.38 & 0.10 & 0.79 \\
\hline Hungary & 7.89 & 0.13 & 4.45 & 0.62 & 0.66 & 3.77 & 6.98 & 2.08 & 4.48 & 11.73 & 4.33 & 7.64 & 0.77 & 1.87 & 0.21 & 8.65 \\
\hline Iceland & 2.07 & 2.12 & 12.95 & 2.93 & 2.08 & 0.57 & 24.05 & 1.39 & 10.44 & 12.89 & 4.91 & 15.04 & 2.21 & 1.02 & 2.99 & 5.42 \\
\hline India & 1.54 & 0.42 & 1.23 & 0.26 & 0.25 & 0.68 & 5.04 & 0.83 & 2.93 & 3.65 & . & 1.23 & 0.29 & 0.23 & 0.47 & . \\
\hline Indonesia & 7.79 & 2.18 & 1.65 & 5.01 & 4.35 & 1.55 & 14.31 & 3.47 & . & 9.58 & 5.21 & 16.66 & 5.96 & 0.66 & 2.07 & 12.65 \\
\hline Ireland & 13.00 & 0.36 & 4.17 & 0.64 & 0.51 & 4.80 & 15.15 & 6.23 & 4.26 & 21.60 & 6.45 & 12.25 & 0.57 & 1.30 & 0.32 & 8.64 \\
\hline Israel & 3.86 & 0.13 & 0.80 & 0.44 & 0.21 & 1.01 & 7.29 & 1.39 & 1.86 & 6.69 & 18.89 & 2.03 & 0.22 & 0.38 & 0.15 & 1.74 \\
\hline Italy & 4.91 & 0.09 & 1.16 & 0.29 & 0.25 & 2.43 & 4.69 & 1.29 & 3.17 & 10.82 & 3.29 & 1.81 & 0.28 & 0.82 & 0.16 & 3.59 \\
\hline
\end{tabular}


Table 3B: Competitiveness-Effect Statistics

\begin{tabular}{|c|c|c|c|c|c|c|c|c|c|c|c|c|c|c|c|c|}
\hline \multirow[b]{2}{*}{ Country $n$} & \multicolumn{16}{|c|}{ CRISIS EVENTS } \\
\hline & $\begin{array}{c}\text { Mexico } \\
1994\end{array}$ & $\begin{array}{c}\text { Ecuad. } \\
1995\end{array}$ & $\begin{array}{c}\text { Argent. } \\
1995\end{array}$ & $\begin{array}{c}\text { Venez. } \\
1995\end{array}$ & $\begin{array}{c}\text { Venez. } \\
1997\end{array}$ & $\begin{array}{c}\text { Czech } \\
1997\end{array}$ & $\begin{array}{c}\text { Thail. } \\
1997\end{array}$ & $\begin{array}{c}\text { Philip. } \\
1997\end{array}$ & $\begin{array}{c}\text { Indon. } \\
1997\end{array}$ & $\begin{array}{c}\text { Korea } \\
1997\end{array}$ & $\begin{array}{c}\text { India } \\
1998\end{array}$ & $\begin{array}{c}\text { Russia } \\
1998\end{array}$ & $\begin{array}{c}\text { Venez. } \\
1998\end{array}$ & $\begin{array}{c}\text { Slovak } \\
1998\end{array}$ & $\begin{array}{c}\text { Ecuad. } \\
1998\end{array}$ & $\begin{array}{c}\text { Brazil } \\
1999\end{array}$ \\
\hline Japan & 2.87 & 0.02 & 0.26 & 0.11 & 0.10 & 0.72 & 1.81 & 0.90 & 0.62 & 6.95 & 0.53 & 1.47 & 0.13 & 0.31 & 0.02 & 1.28 \\
\hline Korea & 7.54 & 0.10 & 1.13 & 0.36 & 0.38 & 1.84 & 6.66 & 4.08 & 4.19 & . & 3.07 & 2.73 & 0.49 & 1.04 & 0.18 & 5.57 \\
\hline Malaysia & 32.64 & 1.94 & 3.36 & 6.40 & 5.72 & 3.71 & 40.40 & 17.17 & 71.43 & 59.60 & 5.16 & 15.30 & 7.07 & 1.48 & 1.67 & 10.61 \\
\hline Mauritius & 6.41 & 0.70 & 3.39 & 1.13 & 0.46 & 1.99 & 45.86 & 10.77 & 11.45 & 14.93 & 18.29 & 1.34 & 0.39 & 1.08 & 0.91 & 70.29 \\
\hline Mexico & . & 0.67 & 1.03 & 2.65 & 5.26 & 2.46 & 6.70 & 2.48 & 5.47 & 14.49 & 2.92 & 10.73 & 6.71 & 0.97 & 1.24 & 5.82 \\
\hline Morocco & 4.45 & 0.47 & 1.81 & 0.19 & 0.19 & 0.71 & 6.04 & 1.74 & 3.70 & 5.81 & 3.33 & 7.89 & 0.26 & 0.32 & 0.63 & . \\
\hline Netherlands & 10.54 & 0.64 & 3.84 & 0.98 & 1.00 & 3.41 & 8.94 & 3.42 & 5.30 & 17.60 & 5.38 & 17.24 & 1.20 & 1.52 & 1.03 & 8.70 \\
\hline New Zealand & 3.52 & 0.30 & 5.17 & 1.54 & 1.32 & 2.30 & 3.60 & 0.63 & 3.10 & 5.73 & 2.23 & 9.44 & 1.58 & 0.83 & 0.35 & 4.78 \\
\hline Norway & 16.18 & 2.79 & 3.87 & 18.16 & 21.86 & 1.14 & 2.92 & 0.72 & 13.08 & 6.92 & 1.75 & 69.73 & 28.16 & 0.83 & 3.51 & 4.09 \\
\hline Oman & 50.53 & 8.59 & 8.69 & 57.49 & 59.71 & 0.87 & 1.69 & 0.76 & 28.24 & 4.69 & 1.53 & 97.31 & 78.46 & 0.39 & 9.16 & . \\
\hline Peru & 3.16 & 0.67 & 0.82 & 0.35 & 0.78 & 0.24 & 1.96 & 1.57 & 3.59 & 5.69 & 2.27 & 4.36 & 0.96 & 0.09 & 0.82 & 4.89 \\
\hline Philippines & 6.15 & 2.37 & 0.95 & 0.35 & 0.17 & 1.25 & 12.69 & . & 9.53 & 25.59 & 4.07 & 2.13 & 0.20 & 0.45 & 2.23 & 3.81 \\
\hline Poland & 5.82 & 0.14 & 1.05 & 0.67 & 0.49 & 3.17 & 3.80 & 1.34 & 4.26 & 9.64 & 2.59 & 5.15 & 0.53 & 0.97 & 0.23 & 3.79 \\
\hline Portugal & 7.64 & 0.20 & 0.97 & 0.25 & 0.28 & 2.62 & 5.27 & 2.55 & 5.35 & 10.76 & 4.55 & 1.98 & 0.34 & 1.02 & 0.35 & 6.42 \\
\hline Romania & 5.12 & 0.09 & 2.38 & 1.66 & 1.02 & 4.10 & 5.93 & 2.35 & 8.98 & 12.96 & 5.37 & 10.09 & 1.10 & 2.18 & 0.11 & 5.30 \\
\hline Russia & . & . & . & . & 6.82 & 1.48 & 1.25 & 0.48 & 5.42 & 4.11 & 1.19 & . & 8.39 & 0.96 & 0.91 & 6.79 \\
\hline Singapore & 46.04 & 1.39 & 3.68 & 1.18 & 1.02 & 6.24 & 60.04 & 27.60 & 23.22 & 100.00 & 9.21 & 15.44 & 1.06 & 1.94 & 0.55 & 10.93 \\
\hline Slovak Rep. & 12.08 & 0.21 & 3.11 & 1.96 & 1.83 & 6.01 & 6.72 & 1.69 & 6.50 & 18.81 & 5.00 & 21.46 & 2.56 & . & 0.24 & 12.43 \\
\hline Slovenia & 14.80 & 0.21 & 1.99 & 1.47 & 1.09 & 6.61 & 9.16 & 2.49 & 9.16 & 21.10 & 5.48 & 7.83 & 1.28 & 2.69 & 0.22 & 8.24 \\
\hline South Africa & 2.29 & 0.07 & 1.39 & 0.61 & 0.94 & 1.64 & 3.34 & 0.92 & 3.62 & 4.74 & 7.29 & 8.25 & 0.47 & 0.56 & 0.12 & 6.77 \\
\hline Spain & 5.70 & 0.18 & 1.20 & 0.34 & 0.35 & 1.76 & 3.12 & 0.89 & 2.01 & 8.76 & 2.35 & 2.92 & 0.43 & 0.76 & 0.32 & 3.94 \\
\hline Sweden & 8.64 & 0.08 & 1.16 & 0.80 & 0.45 & 3.35 & 4.21 & 1.63 & 3.29 & 11.52 & 2.27 & 10.20 & 0.55 & 1.43 & 0.16 & 7.98 \\
\hline Switzerland & 4.62 & 0.07 & 0.94 & 0.28 & 0.26 & 2.53 & 4.51 & 1.20 & 2.21 & 8.92 & 5.35 & 2.01 & 0.32 & 0.79 & 0.08 & 3.13 \\
\hline Thailand & 10.74 & 2.14 & 2.44 & 0.56 & 0.48 & 2.22 & . & 5.80 & 17.93 & 19.09 & 12.81 & 4.45 & 0.93 & 0.88 & 2.82 & . \\
\hline Tunisia & 14.02 & 0.86 & 1.75 & 3.97 & 4.21 & 2.60 & 9.28 & 5.20 & 10.15 & 9.78 & 8.59 & 9.61 & 4.92 & 1.19 & 0.96 & 2.78 \\
\hline Turkey & 4.21 & 0.11 & 1.32 & 0.40 & 0.35 & 1.83 & 3.82 & 1.59 & 3.67 & 7.39 & 6.47 & 3.19 & 0.40 & 0.61 & 0.14 & 2.93 \\
\hline U.K. & 6.22 & 0.29 & 1.02 & 1.71 & 1.90 & 1.79 & 3.94 & 1.52 & 2.69 & 9.33 & 2.81 & 4.66 & 2.06 & 0.59 & 0.29 & 2.56 \\
\hline U.S. & 1.89 & 0.04 & 0.72 & 0.14 & 0.13 & 0.63 & 1.39 & 0.64 & 0.73 & 3.40 & 0.66 & 1.46 & 0.15 & 0.23 & 0.04 & 1.64 \\
\hline Venezuela & 19.27 & 3.56 & 3.69 & . & . & 0.97 & 1.24 & 0.20 & 14.06 & 2.79 & 1.37 & 41.34 & . & 0.56 & 3.80 & 3.73 \\
\hline
\end{tabular}




\section{Table 3C: Competitiveness-Effect Statistics (Summary Statistics)}

\begin{tabular}{|c|c|c|c|c|c|c|c|c|c|c|c|c|c|c|c|c|}
\hline & \multicolumn{16}{|c|}{ CRISIS EVENTS } \\
\hline & $\begin{array}{c}\text { Mexico } \\
1994\end{array}$ & $\begin{array}{c}\text { Ecuad. } \\
1995\end{array}$ & $\begin{array}{c}\text { Argent. } \\
1995\end{array}$ & $\begin{array}{c}\text { Venez. } \\
1995\end{array}$ & $\begin{array}{c}\text { Venez. } \\
1997\end{array}$ & $\begin{array}{c}\text { Czech } \\
1997\end{array}$ & $\begin{array}{c}\text { Thail. } \\
1997\end{array}$ & $\begin{array}{c}\text { Philip. } \\
1997\end{array}$ & $\begin{array}{c}\text { Indon. } \\
1997\end{array}$ & $\begin{array}{c}\text { Korea } \\
1997\end{array}$ & $\begin{array}{c}\text { India } \\
1998\end{array}$ & $\begin{array}{c}\text { Russia } \\
1998\end{array}$ & $\begin{array}{c}\text { Venez. } \\
1998\end{array}$ & $\begin{array}{c}\text { Slovak } \\
1998\end{array}$ & $\begin{array}{c}\text { Ecuad. } \\
1998\end{array}$ & $\begin{array}{c}\text { Brazil } \\
1999\end{array}$ \\
\hline Mean & 8.79 & 0.84 & 2.28 & 2.69 & 2.85 & 2.26 & 8.15 & 2.90 & 7.90 & 12.59 & 4.85 & 10.97 & 3.60 & 0.94 & 0.99 & 6.86 \\
\hline Std. Dev. & 9.52 & 1.47 & 2.08 & 8.10 & 8.43 & 1.72 & 10.82 & 4.39 & 10.45 & 14.83 & 4.21 & 16.12 & 11.03 & 0.70 & 1.57 & 9.58 \\
\hline Minimum & 1.36 & 0.02 & 0.26 & 0.08 & 0.10 & 0.24 & 1.24 & 0.20 & 0.62 & 0.91 & 0.53 & 0.46 & 0.13 & 0.09 & 0.02 & 0.62 \\
\hline Maximum & 50.53 & 8.59 & 12.95 & 57.49 & 59.71 & 7.67 & 60.04 & 27.60 & 71.43 & 100.00 & 19.46 & 97.31 & 78.46 & 3.10 & 9.16 & 70.29 \\
\hline
\end{tabular}

\begin{tabular}{lc}
\hline \multicolumn{2}{c}{ Sample Statistics } \\
\hline Mean & 4.97 \\
Standard Deviation & 9.33 \\
Minimum & 0.02 \\
Maximum & 100.00 \\
\hline
\end{tabular}


Table 4A: Income-Effect Statistics

\begin{tabular}{|c|c|c|c|c|c|c|c|c|c|c|c|c|c|c|c|c|}
\hline \multirow[b]{2}{*}{ Country $n$} & \multicolumn{16}{|c|}{ CRISIS EVENTS } \\
\hline & $\begin{array}{c}\text { Mexico } \\
1994\end{array}$ & $\begin{array}{c}\text { Ecuad. } \\
1995\end{array}$ & $\begin{array}{c}\text { Argent. } \\
1995\end{array}$ & $\begin{array}{c}\text { Venez. } \\
1995\end{array}$ & $\begin{array}{c}\text { Venez. } \\
1997\end{array}$ & $\begin{array}{c}\text { Czech } \\
1997\end{array}$ & $\begin{array}{c}\text { Thail. } \\
1997\end{array}$ & $\begin{array}{c}\text { Philip. } \\
1997\end{array}$ & $\begin{array}{c}\text { Indon. } \\
1997\end{array}$ & $\begin{array}{c}\text { Korea } \\
1997\end{array}$ & $\begin{array}{c}\text { India } \\
1998\end{array}$ & $\begin{array}{c}\text { Russia } \\
1998\end{array}$ & $\begin{array}{c}\text { Venez. } \\
1998\end{array}$ & $\begin{array}{c}\text { Slovak } \\
1998\end{array}$ & $\begin{array}{c}\text { Ecuad. } \\
1998\end{array}$ & $\begin{array}{c}\text { Brazil } \\
1999\end{array}$ \\
\hline Argentina & 0.11 & 0.03 & . & 0.08 & 0.13 & 0.00 & 0.05 & 0.02 & 0.08 & 0.07 & 0.07 & 0.08 & 0.11 & 0.00 & 0.03 & 2.57 \\
\hline Australia & 0.04 & 0.00 & 0.01 & 0.00 & 0.00 & 0.01 & 0.29 & 0.20 & 0.45 & 1.30 & 0.23 & 0.02 & 0.00 & 0.00 & 0.00 & 0.07 \\
\hline Austria & 0.05 & 0.00 & 0.04 & 0.01 & 0.02 & 0.74 & 0.08 & 0.02 & 0.12 & 0.13 & 0.05 & 0.39 & 0.02 & 0.38 & 0.00 & 0.12 \\
\hline Bangladesh & 0.01 & 0.00 & 0.01 & 0.00 & 0.00 & 0.00 & 0.04 & 0.03 & 0.01 & 0.03 & 0.06 & 0.04 & 0.00 & . & 0.00 & 0.03 \\
\hline Belgium & 0.16 & 0.02 & 0.08 & 0.03 & 0.03 & 0.24 & 0.31 & 0.06 & 0.11 & 0.19 & 1.17 & 0.64 & 0.04 & 0.06 & 0.01 & 0.34 \\
\hline Brazil & 0.19 & 0.05 & 0.76 & 0.05 & 0.06 & 0.00 & 0.05 & 0.04 & 0.04 & 0.11 & 0.02 & 0.09 & 0.09 & 0.01 & 0.02 & . \\
\hline Canada & 0.14 & 0.01 & 0.03 & 0.08 & 0.07 & 0.01 & 0.07 & 0.03 & 0.11 & 0.34 & 0.05 & 0.04 & 0.11 & 0.00 & 0.01 & 0.16 \\
\hline Chile & 0.41 & 0.17 & 1.28 & 0.15 & 0.21 & 0.00 & 0.17 & 0.15 & 0.22 & 1.30 & 0.10 & 0.06 & 0.21 & . & 0.21 & 1.05 \\
\hline China & 0.04 & 0.01 & 0.05 & 0.01 & 0.01 & 0.02 & 0.15 & 0.12 & 0.17 & 0.92 & 0.10 & 0.23 & 0.01 & 0.00 & 0.01 & 0.11 \\
\hline Colombia & 0.13 & 0.40 & 0.08 & 0.67 & 0.78 & 0.00 & 0.01 & 0.00 & 0.00 & 0.03 & 0.00 & 0.06 & 0.91 & 0.00 & 0.50 & 0.10 \\
\hline Croatia & 0.00 & 0.07 & 0.00 & 0.00 & 0.03 & 0.20 & 0.01 & 0.00 & 0.00 & 0.00 & 0.01 & 0.81 & 0.00 & 0.11 & 0.02 & 0.00 \\
\hline Cyprus & 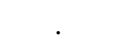 & 0.00 & . & . & . & 0.02 & 0.02 & 0.00 & 0.00 & 0.01 & 0.01 & 0.14 & . & 0.03 & 0.00 & . \\
\hline Czech Rep. & 0.04 & 0.02 & 0.04 & 0.01 & 0.01 & . & 0.08 & 0.01 & 0.03 & 0.08 & 0.12 & 1.46 & 0.01 & 5.54 & 0.02 & 0.07 \\
\hline Denmark & 0.09 & 0.00 & 0.05 & 0.03 & 0.02 & 0.10 & 0.10 & 0.03 & 0.08 & 0.25 & 0.06 & 0.50 & 0.02 & 0.02 & 0.01 & 0.09 \\
\hline Ecuador & 0.46 & . & 0.43 & 0.05 & 0.38 & 0.00 & 0.00 & 0.01 & 0.00 & 1.65 & 0.01 & 0.71 & 0.25 & 0.00 & . & 0.18 \\
\hline Egypt & 0.00 & . & 0.00 & 0.00 & 0.00 & 0.00 & 0.00 & 0.00 & 0.00 & 0.05 & 0.06 & 0.03 & 0.00 & 0.00 & . & 0.02 \\
\hline Estonia & 0.00 & . & 0.00 & 0.00 & 0.00 & 0.06 & 0.00 & 0.07 & 0.01 & 0.24 & 0.06 & 11.53 & 0.01 & 0.02 & . & 0.00 \\
\hline Finland & 0.06 & 0.01 & 0.08 & 0.03 & 0.03 & 0.20 & 0.30 & 0.12 & 0.24 & 0.47 & 0.20 & 2.46 & 0.03 & 0.05 & 0.00 & 0.24 \\
\hline France & 0.10 & 0.00 & 0.08 & 0.02 & 0.02 & 0.08 & 0.06 & 0.03 & 0.08 & 0.13 & 0.06 & 0.18 & 0.02 & 0.03 & 0.01 & 0.14 \\
\hline Germany & 0.14 & 0.01 & 0.06 & 0.02 & 0.02 & 0.39 & 0.15 & 0.06 & 0.11 & 0.28 & 0.12 & 0.45 & 0.03 & 0.13 & 0.01 & 0.26 \\
\hline Greece & 0.02 & 0.00 & 0.01 & 0.00 & 0.00 & 0.04 & 0.04 & 0.01 & 0.06 & 0.04 & 0.02 & 0.35 & 0.00 & 0.01 & 0.00 & 0.06 \\
\hline Hong Kong & 0.11 & 0.00 & 0.03 & 0.00 & 0.00 & 0.00 & 0.22 & 0.21 & 0.13 & 0.22 & 0.03 & 0.01 & 0.00 & . & 0.00 & 0.04 \\
\hline Hungary & 0.01 & 0.00 & 0.02 & 0.01 & 0.00 & 0.64 & 0.03 & 0.01 & 0.02 & 0.03 & 0.05 & 2.07 & 0.00 & 0.53 & 0.00 & 0.18 \\
\hline Iceland & 0.00 & . & 0.00 & 0.00 & 0.00 & 0.02 & 0.01 & 0.00 & 0.00 & 0.10 & 0.01 & 0.45 & 0.00 & 0.00 & . & 0.11 \\
\hline India & 0.02 & 0.00 & 0.01 & 0.00 & 0.00 & 0.01 & 0.11 & 0.05 & 0.15 & 0.13 & . & 0.23 & 0.01 & 0.00 & 0.00 & 0.00 \\
\hline Indonesia & 0.08 & 0.00 & 0.03 & 0.01 & 0.01 & 0.01 & 0.36 & 0.30 & . & 1.44 & 0.32 & 0.04 & 0.01 & 0.00 & 0.01 & 0.18 \\
\hline Ireland & 0.17 & 0.01 & 0.06 & 0.02 & 0.03 & 0.18 & 0.15 & 0.32 & 0.04 & 0.46 & 0.07 & 0.44 & 0.02 & 0.03 & 0.01 & 0.20 \\
\hline Israel & 0.10 & 0.02 & 0.10 & 0.03 & 0.01 & 0.05 & 0.35 & 0.21 & 0.01 & 0.38 & 0.37 & 0.26 & 0.02 & 0.02 & 0.03 & 0.30 \\
\hline Italy & 0.09 & 0.01 & 0.14 & 0.04 & 0.04 & 0.14 & 0.11 & 0.03 & 0.09 & 0.23 & 0.09 & 0.34 & 0.05 & 0.06 & 0.01 & 0.28 \\
\hline
\end{tabular}


Table 4B: Income-Effect Statistics

\begin{tabular}{|c|c|c|c|c|c|c|c|c|c|c|c|c|c|c|c|c|}
\hline \multirow[b]{2}{*}{ Country $n$} & \multicolumn{16}{|c|}{ CRISIS EVENTS } \\
\hline & $\begin{array}{c}\text { Mexico } \\
1994\end{array}$ & $\begin{array}{l}\text { Ecuad. } \\
1995\end{array}$ & $\begin{array}{c}\text { Argent. } \\
1995\end{array}$ & $\begin{array}{c}\text { Venez. } \\
1995\end{array}$ & $\begin{array}{c}\text { Venez. } \\
1997\end{array}$ & $\begin{array}{c}\text { Czech } \\
1997\end{array}$ & $\begin{array}{l}\text { Thail. } \\
1997\end{array}$ & $\begin{array}{c}\text { Philip. } \\
1997\end{array}$ & $\begin{array}{c}\text { Indon. } \\
1997\end{array}$ & $\begin{array}{c}\text { Korea } \\
1997\end{array}$ & $\begin{array}{c}\text { India } \\
1998\end{array}$ & $\begin{array}{c}\text { Russia } \\
1998\end{array}$ & $\begin{array}{c}\text { Venez. } \\
1998\end{array}$ & $\begin{array}{c}\text { Slovak } \\
1998\end{array}$ & $\begin{array}{c}\text { Ecuad. } \\
1998\end{array}$ & $\begin{array}{c}\text { Brazil } \\
1999\end{array}$ \\
\hline Japan & 0.09 & 0.01 & 0.01 & 0.01 & 0.01 & 0.00 & 0.40 & 0.18 & 0.20 & 0.64 & 0.05 & 0.02 & 0.02 & 0.00 & 0.01 & 0.07 \\
\hline Korea & 0.32 & 0.03 & 0.12 & 0.02 & 0.02 & 0.04 & 0.51 & 0.37 & 0.61 & . & 0.24 & 0.37 & 0.05 & 0.01 & 0.02 & 0.56 \\
\hline Malaysia & 0.54 & 0.01 & 0.08 & 0.02 & 0.02 & 0.02 & 3.18 & 0.93 & 1.21 & 2.39 & 1.18 & 0.09 & 0.05 & 0.00 & 0.00 & 0.37 \\
\hline Mauritius & 0.00 & $\cdot$ & 0.01 & . & $\cdot$ & 0.00 & 0.05 & 0.01 & 0.00 & 0.01 & 0.33 & 0.00 & . & . & . & 0.03 \\
\hline Mexico & . & 0.03 & 0.07 & 0.05 & 0.15 & 0.00 & 0.03 & 0.02 & 0.02 & 0.10 & 0.02 & 0.01 & 0.23 & . & 0.05 & 0.19 \\
\hline Morocco & 0.11 & 0.00 & 0.00 & 0.01 & 0.01 & 0.01 & 0.00 & 0.00 & 0.05 & 0.03 & 1.16 & 0.12 & 0.02 & 0.00 & 0.00 & 0.00 \\
\hline Netherlands & 0.07 & 0.01 & 0.05 & 0.03 & 0.02 & 0.16 & 0.13 & 0.07 & 0.10 & 0.23 & 0.13 & 0.53 & 0.03 & 0.07 & 0.02 & 0.13 \\
\hline New Zealand & 0.22 & 0.00 & 0.04 & 0.10 & 0.09 & 0.00 & 0.28 & 0.26 & 0.35 & 1.03 & 0.14 & 0.32 & 0.11 & 0.00 & 0.00 & 0.14 \\
\hline Norway & 0.02 & 0.00 & 0.01 & 0.01 & 0.01 & 0.04 & 0.10 & 0.06 & 0.03 & 0.15 & 0.05 & 0.22 & 0.03 & 0.01 & 0.00 & 0.16 \\
\hline Oman & . & . & 0.00 & 0.00 & 0.00 & . & 0.05 & 0.02 & 0.00 & 0.11 & 0.52 & 0.15 & 0.00 & . & . & . \\
\hline Peru & 0.33 & 0.12 & 0.05 & 0.17 & 0.21 & 0.00 & 0.06 & 0.05 & 0.05 & 0.24 & 0.03 & 0.01 & 0.22 & 0.00 & 0.17 & 0.29 \\
\hline Philippines & 0.06 & 0.00 & 0.01 & 0.00 & 0.00 & 0.00 & 0.94 & . & 0.17 & 0.45 & 0.04 & 0.01 & 0.00 & 0.00 & 0.00 & 0.04 \\
\hline Poland & 0.03 & 0.00 & 0.02 & 0.01 & 0.01 & 0.58 & 0.10 & 0.03 & 0.03 & 0.08 & 0.04 & 1.49 & 0.02 & 0.21 & 0.00 & 0.07 \\
\hline Portugal & 0.02 & 0.00 & 0.07 & 0.01 & 0.01 & 0.02 & 0.02 & 0.01 & 0.00 & 0.03 & 0.02 & 0.07 & 0.01 & 0.01 & 0.00 & 0.21 \\
\hline Romania & 0.02 & 0.02 & 0.14 & 0.01 & 0.06 & 0.06 & 0.13 & 0.05 & 0.03 & 0.14 & 0.18 & 0.72 & 0.07 & 0.07 & 0.01 & 0.02 \\
\hline Russia & 0.00 & 0.00 & 0.00 & 0.00 & 0.00 & 0.42 & 0.05 & 0.03 & 0.01 & 0.24 & 0.21 & . & 0.00 & 0.40 & 0.01 & 0.06 \\
\hline Singapore & 0.29 & 0.01 & 0.27 & 0.04 & 0.01 & 0.02 & 7.76 & 2.51 & . & 4.15 & 2.33 & 0.78 & 0.02 & 0.00 & 0.00 & 0.35 \\
\hline Slovak Rep. & 0.21 & 0.03 & 0.08 & 0.00 & 0.00 & 14.58 & 0.11 & 0.01 & 0.12 & 0.04 & 0.19 & 1.69 & 0.01 & . & 0.01 & 0.02 \\
\hline Slovenia & 0.01 & 0.02 & 0.04 & 0.01 & 0.01 & 0.78 & 0.04 & 0.01 & 0.02 & 0.05 & 0.06 & 1.79 & 0.02 & 0.31 & 0.01 & 0.08 \\
\hline South Africa & 0.03 & 0.01 & 0.06 & 0.02 & 0.03 & 0.00 & 0.10 & 0.04 & 0.12 & 0.47 & 0.13 & 0.03 & 0.05 & 0.00 & 0.01 & 0.13 \\
\hline Spain & 0.28 & 0.01 & 0.19 & 0.03 & 0.04 & 0.06 & 0.05 & 0.02 & 0.06 & 0.11 & 0.04 & 0.16 & 0.06 & 0.02 & 0.03 & 0.24 \\
\hline Sweden & 0.11 & 0.01 & 0.10 & 0.03 & 0.03 & 0.14 & 0.26 & 0.10 & 0.21 & 0.26 & 0.13 & 0.40 & 0.05 & 0.04 & 0.01 & 0.40 \\
\hline Switzerland & 0.15 & 0.02 & 0.09 & 0.03 & 0.03 & 0.15 & 0.25 & 0.07 & 0.12 & 0.32 & 0.16 & 0.16 & 0.04 & 0.06 & 0.02 & 0.32 \\
\hline Thailand & 0.08 & 0.00 & 0.03 & 0.00 & 0.00 & 0.02 & . & 0.35 & 0.53 & 0.56 & 0.20 & 0.08 & 0.01 & 0.00 & 0.00 & 0.00 \\
\hline Tunisia & 0.00 & 0.00 & 0.02 & 0.03 & 0.00 & 0.00 & . & . & 0.08 & 0.01 & 0.81 & 0.02 & 0.00 & 0.00 & 0.00 & 0.12 \\
\hline Turkey & 0.01 & 0.01 & 0.02 & 0.01 & 0.01 & 0.05 & 0.04 & 0.03 & 0.03 & 0.06 & 0.03 & 1.08 & 0.00 & 0.01 & 0.00 & 0.02 \\
\hline UK & 0.06 & 0.01 & 0.03 & 0.03 & 0.02 & 0.10 & 0.13 & 0.05 & 0.11 & 0.18 & 0.20 & 0.16 & 0.03 & 0.02 & 0.01 & 0.11 \\
\hline US & 0.73 & 0.02 & 0.06 & 0.06 & 0.06 & 0.01 & 0.09 & 0.08 & 0.05 & 0.34 & 0.04 & 0.04 & 0.08 & 0.00 & 0.02 & 0.17 \\
\hline Venezuela & 0.43 & 0.25 & 0.06 & . & . & . & 0.00 & 0.00 & 0.00 & 0.02 & 0.01 & 0.03 & . & . & 0.34 & 0.70 \\
\hline
\end{tabular}


Table 4C: Income-Effect Statistics (Summary Statistics)

\begin{tabular}{|c|c|c|c|c|c|c|c|c|c|c|c|c|c|c|c|c|}
\hline & \multicolumn{16}{|c|}{ CRISIS EVENTS } \\
\hline & $\begin{array}{c}\text { Mexico } \\
1994\end{array}$ & $\begin{array}{c}\text { Ecuad. } \\
1995\end{array}$ & $\begin{array}{c}\text { Argent. } \\
1995\end{array}$ & $\begin{array}{c}\text { Venez. } \\
1995\end{array}$ & $\begin{array}{c}\text { Venez. } \\
1997\end{array}$ & $\begin{array}{c}\text { Czech } \\
1997\end{array}$ & $\begin{array}{l}\text { Thail. } \\
1997\end{array}$ & $\begin{array}{c}\text { Philip. } \\
1997\end{array}$ & $\begin{array}{c}\text { Indon. } \\
1997\end{array}$ & $\begin{array}{c}\text { Korea } \\
1997\end{array}$ & $\begin{array}{c}\text { India } \\
1998\end{array}$ & $\begin{array}{c}\text { Russia } \\
1998\end{array}$ & $\begin{array}{c}\text { Venez. } \\
1998\end{array}$ & $\begin{array}{c}\text { Slovak } \\
1998\end{array}$ & $\begin{array}{c}\text { Ecuad. } \\
1998\end{array}$ & $\begin{array}{c}\text { Brazil } \\
1999\end{array}$ \\
\hline Mean & 0.13 & 0.03 & 0.09 & 0.04 & 0.05 & 0.37 & 0.33 & 0.13 & 0.12 & 0.40 & 0.21 & 0.61 & 0.06 & 0.17 & 0.03 & 0.23 \\
\hline Std. Dev. & 0.15 & 0.07 & 0.20 & 0.09 & 0.12 & 1.96 & 1.10 & 0.36 & 0.20 & 0.69 & 0.40 & 1.57 & 0.13 & 0.78 & 0.09 & 0.38 \\
\hline Minimum & 0.00 & 0.00 & 0.00 & 0.00 & 0.00 & 0.00 & 0.00 & 0.00 & 0.00 & 0.00 & 0.00 & 0.00 & 0.00 & 0.00 & 0.00 & 0.00 \\
\hline Maximum & 0.73 & 0.40 & 1.28 & 0.67 & 0.78 & 14.58 & 7.76 & 2.51 & 1.21 & 4.15 & 2.33 & 11.53 & 0.91 & 5.54 & 0.50 & 2.57 \\
\hline
\end{tabular}

\begin{tabular}{lc}
\hline \multicolumn{2}{c}{ Sample Statistics } \\
\hline Mean & 0.19 \\
Standard Deviation & 0.78 \\
Minimum & 0.00 \\
Maximum & 14.58 \\
\hline
\end{tabular}


Table 5A: Cheap-Import Effect Statistics

\begin{tabular}{|c|c|c|c|c|c|c|c|c|c|c|c|c|c|c|c|c|}
\hline \multirow[b]{2}{*}{ Country $n$} & \multicolumn{16}{|c|}{ CRISIS EVENTS } \\
\hline & $\begin{array}{c}\text { Mexico } \\
1994\end{array}$ & $\begin{array}{c}\text { Ecuad. } \\
1995\end{array}$ & $\begin{array}{c}\text { Argent. } \\
1995\end{array}$ & $\begin{array}{c}\text { Venez. } \\
1995\end{array}$ & $\begin{array}{c}\text { Venez. } \\
1997\end{array}$ & $\begin{array}{c}\text { Czech } \\
1997\end{array}$ & $\begin{array}{c}\text { Thail. } \\
1997\end{array}$ & $\begin{array}{c}\text { Philip. } \\
1997\end{array}$ & $\begin{array}{c}\text { Indon. } \\
1997\end{array}$ & $\begin{array}{c}\text { Korea } \\
1997\end{array}$ & $\begin{array}{c}\text { India } \\
1998\end{array}$ & $\begin{array}{c}\text { Russia } \\
1998\end{array}$ & $\begin{array}{c}\text { Venez. } \\
1998\end{array}$ & $\begin{array}{c}\text { Slovak } \\
1998\end{array}$ & $\begin{array}{c}\text { Ecuad. } \\
1998\end{array}$ & $\begin{array}{c}\text { Brazil } \\
1999\end{array}$ \\
\hline Argentina & 0.11 & 0.04 & & 0.02 & 0.05 & 0.01 & 0.03 & 0.01 & 0.03 & 0.18 & 0.05 & 0.05 & 0.02 & 0.01 & 0.04 & 2.59 \\
\hline Australia & 0.03 & 0.00 & 0.02 & 0.00 & 0.00 & 0.01 & 0.25 & 0.07 & 0.40 & 0.53 & 0.14 & 0.00 & 0.00 & 0.00 & 0.00 & 0.06 \\
\hline Austria & 0.04 & 0.02 & 0.01 & 0.00 & 0.00 & 0.74 & 0.07 & 0.03 & 0.08 & 0.13 & 0.10 & 0.23 & 0.00 & 0.39 & 0.02 & 0.10 \\
\hline Bangladesh & 0.00 & 0.00 & 0.00 & . & & 0.00 & 0.18 & 0.00 & 0.17 & 1.14 & 3.20 & 0.24 & . & . & 0.00 & 0.13 \\
\hline Belgium & 0.14 & 0.02 & 0.15 & 0.06 & 0.05 & 0.17 & 0.33 & 0.05 & 0.25 & 0.17 & 0.65 & 0.75 & 0.07 & 0.07 & 0.08 & 0.76 \\
\hline Brazil & 0.08 & 0.00 & 0.86 & 0.13 & 0.16 & 0.01 & 0.03 & 0.00 & 0.04 & 0.19 & 0.04 & 0.05 & 0.16 & 0.01 & 0.00 & . \\
\hline Canada & 0.78 & 0.02 & 0.02 & 0.09 & 0.12 & 0.02 & 0.17 & 0.09 & 0.10 & 0.45 & 0.11 & 0.09 & 0.15 & 0.01 & 0.02 & 0.19 \\
\hline Chile & 0.60 & 0.42 & 2.17 & 0.32 & 0.50 & 0.00 & 0.08 & 0.03 & 0.15 & 0.88 & 0.10 & 0.02 & 0.40 & . & 0.38 & 1.52 \\
\hline China & 0.02 & 0.00 & 0.06 & 0.01 & 0.00 & 0.01 & 0.27 & 0.05 & 0.32 & 1.77 & 0.12 & 0.54 & 0.00 & 0.00 & 0.01 & 0.14 \\
\hline Colombia & 0.45 & 0.35 & 0.27 & 1.53 & 1.47 & 0.02 & 0.02 & 0.01 & 0.04 & 0.21 & 0.06 & 0.09 & 1.66 & 0.01 & 0.40 & 0.57 \\
\hline Croatia & 0.02 & 0.14 & 0.08 & 0.00 & 0.00 & 1.26 & 0.03 & 0.00 & 0.04 & 0.20 & 0.13 & 2.49 & 0.02 & 0.44 & 0.13 & 0.39 \\
\hline Cyprus & 0.02 & 0.00 & 0.41 & 0.00 & 0.00 & 0.10 & 0.35 & 0.04 & 0.27 & 0.68 & 0.34 & 2.13 & 0.05 & 0.04 & 0.00 & 0.15 \\
\hline Czech Rep. & 0.02 & 0.06 & 0.06 & 0.00 & 0.00 & . & 0.09 & 0.02 & 0.09 & 0.36 & 0.14 & 4.03 & 0.01 & 4.98 & 0.03 & 0.22 \\
\hline Denmark & 0.01 & 0.01 & 0.20 & 0.01 & 0.04 & 0.10 & 0.16 & 0.03 & 0.14 & 0.18 & 0.16 & 0.22 & 0.04 & 0.02 & 0.00 & 0.20 \\
\hline Ecuador & 1.04 & . & 0.34 & 1.10 & 1.12 & 0.02 & 0.01 & 0.00 & 0.07 & 0.39 & 0.02 & 0.21 & 1.75 & 0.01 & . & 1.13 \\
\hline Egypt & 0.01 & 0.00 & 0.19 & 0.00 & 0.00 & 0.07 & 0.06 & 0.02 & 0.16 & 0.30 & 0.31 & 0.53 & 0.01 & 0.01 & 0.00 & 0.42 \\
\hline Estonia & . & . & . & . & . & 0.51 & 0.08 & 0.00 & 0.14 & 1.38 & 0.24 & 15.01 & . & 0.28 & 0.07 & . \\
\hline Finland & 0.03 & 0.03 & 0.03 & 0.02 & 0.01 & 0.13 & 0.14 & 0.06 & 0.13 & 0.20 & 0.09 & 2.69 & 0.02 & 0.05 & 0.01 & 0.21 \\
\hline France & 0.05 & 0.01 & 0.03 & 0.01 & 0.02 & 0.05 & 0.13 & 0.03 & 0.09 & 0.14 & 0.10 & 0.33 & 0.02 & 0.02 & 0.01 & 0.18 \\
\hline Germany & 0.03 & 0.02 & 0.06 & 0.03 & 0.02 & 0.41 & 0.12 & 0.07 & 0.12 & 0.23 & 0.15 & 0.60 & 0.02 & 0.15 & 0.02 & 0.23 \\
\hline Greece & 0.01 & 0.01 & 0.08 & 0.01 & 0.00 & 0.09 & 0.07 & 0.01 & 0.10 & 0.55 & 0.10 & 0.56 & 0.00 & 0.03 & 0.01 & 0.09 \\
\hline Hong Kong & 0.08 & 0.00 & 0.16 & 0.00 & 0.01 & 0.06 & 2.15 & 0.67 & 1.14 & 7.60 & 1.29 & 0.47 & 0.01 & . & 0.00 & 0.37 \\
\hline Hungary & 0.01 & 0.02 & 0.02 & 0.00 & 0.00 & 1.19 & 0.06 & 0.01 & 0.09 & 0.36 & 0.11 & 4.46 & 0.00 & 0.97 & 0.01 & 0.44 \\
\hline Iceland & 0.01 & 0.00 & 0.00 & 0.00 & 0.00 & 0.13 & 0.09 & 0.01 & 0.05 & 0.40 & 0.09 & 0.86 & 0.00 & 0.02 & 0.00 & 0.04 \\
\hline India & 0.01 & 0.00 & 0.02 & 0.00 & 0.00 & 0.02 & 0.05 & 0.00 & 0.16 & 0.24 & . & 0.17 & 0.00 & 0.01 & 0.00 & 0.00 \\
\hline Indonesia & 0.03 & 0.00 & 0.07 & 0.00 & 0.01 & 0.02 & 0.52 & 0.04 & . & 1.14 & 0.35 & 0.14 & 0.00 & 0.00 & 0.00 & 0.26 \\
\hline Ireland & 0.03 & 0.02 & 0.03 & 0.00 & 0.01 & 0.08 & 0.50 & 0.12 & 0.12 & 0.77 & 0.16 & 0.02 & 0.01 & 0.02 & 0.00 & 0.09 \\
\hline Israel & 0.01 & 0.01 & 0.07 & 0.01 & 0.00 & 0.03 & 0.21 & 0.01 & 0.00 & 0.43 & 0.35 & 0.19 & 0.00 & 0.00 & 0.01 & 0.08 \\
\hline Italy & 0.01 & 0.02 & 0.09 & 0.02 & 0.03 & 0.08 & 0.07 & 0.02 & 0.10 & 0.11 & 0.15 & 0.47 & 0.03 & 0.07 & 0.02 & 0.24 \\
\hline
\end{tabular}


Table 5B: Cheap-Import Effect Statistics

\begin{tabular}{|c|c|c|c|c|c|c|c|c|c|c|c|c|c|c|c|c|}
\hline \multirow[b]{2}{*}{ Country $n$} & \multicolumn{16}{|c|}{ CRISIS EVENTS } \\
\hline & $\begin{array}{c}\text { Mexico } \\
1994\end{array}$ & $\begin{array}{c}\text { Ecuad. } \\
1995\end{array}$ & $\begin{array}{c}\text { Argent. } \\
1995\end{array}$ & $\begin{array}{c}\text { Venez. } \\
1995\end{array}$ & $\begin{array}{c}\text { Venez. } \\
1997\end{array}$ & $\begin{array}{c}\text { Czech } \\
1997\end{array}$ & $\begin{array}{c}\text { Thail. } \\
1997\end{array}$ & $\begin{array}{c}\text { Philip. } \\
1997\end{array}$ & $\begin{array}{c}\text { Indon. } \\
1997\end{array}$ & $\begin{array}{c}\text { Korea } \\
1997\end{array}$ & $\begin{array}{c}\text { India } \\
1998\end{array}$ & $\begin{array}{c}\text { Russia } \\
1998\end{array}$ & $\begin{array}{c}\text { Venez. } \\
1998\end{array}$ & $\begin{array}{c}\text { Slovak } \\
1998\end{array}$ & $\begin{array}{c}\text { Ecuad. } \\
1998\end{array}$ & $\begin{array}{c}\text { Brazil } \\
1999\end{array}$ \\
\hline Japan & 0.03 & 0.00 & 0.01 & 0.01 & 0.01 & 0.00 & 0.25 & 0.11 & 0.37 & 0.39 & 0.07 & 0.11 & 0.01 & 0.00 & 0.01 & 0.08 \\
\hline Korea & 0.06 & 0.09 & 0.02 & 0.02 & 0.01 & 0.01 & 0.25 & 0.12 & 0.82 & . & 0.22 & 0.35 & 0.01 & 0.00 & 0.05 & 0.28 \\
\hline Malaysia & 0.02 & 0.00 & 0.12 & 0.00 & 0.00 & 0.01 & 2.93 & 0.90 & 1.61 & 4.60 & 0.87 & 0.42 & 0.00 & 0.00 & 0.00 & 0.30 \\
\hline Mauritius & 0.00 & $\cdot$ & 0.53 & . & . & 0.01 & 0.39 & 0.08 & 0.65 & 0.72 & 5.70 & 0.06 & . & $\cdot$ & $\cdot$ & 0.15 \\
\hline Mexico & . & 0.02 & 0.08 & 0.08 & 0.08 & 0.01 & 0.08 & 0.04 & 0.08 & 0.34 & 0.07 & 0.06 & 0.14 & . & 0.02 & 0.28 \\
\hline Morocco & 0.02 & 0.00 & 0.27 & 0.01 & 0.01 & 0.04 & 0.04 & 0.01 & 0.08 & 0.18 & 0.13 & 0.62 & 0.01 & 0.01 & 0.00 & 0.00 \\
\hline Netherlands & 0.05 & 0.01 & 0.30 & 0.10 & 0.10 & 0.12 & 0.40 & 0.12 & 0.38 & 0.29 & 0.26 & 0.63 & 0.06 & 0.05 & 0.02 & 0.57 \\
\hline New Zealand & 0.03 & 0.03 & 0.04 & 0.00 & 0.00 & 0.01 & 0.21 & 0.06 & 0.26 & 0.49 & 0.16 & 0.01 & 0.01 & 0.00 & 0.05 & 0.06 \\
\hline Norway & 0.03 & 0.01 & 0.03 & 0.02 & 0.02 & 0.08 & 0.09 & 0.02 & 0.06 & 0.18 & 0.11 & 0.63 & 0.05 & 0.01 & 0.01 & 0.20 \\
\hline Oman & 0.01 & . & 0.12 & 0.00 & . & . & . & . & . & . & . & . & . & . & . & $\cdot$ \\
\hline Peru & 0.34 & 0.33 & 0.62 & 0.32 & 1.01 & 0.01 & 0.06 & 0.00 & 0.03 & 0.41 & 0.04 & 0.04 & 0.93 & 0.00 & 0.39 & 0.63 \\
\hline Philippines & 0.04 & 0.00 & 0.02 & 0.02 & 0.00 & 0.01 & 0.82 & . & 0.88 & 2.23 & 0.33 & 0.59 & 0.00 & 0.00 & 0.00 & 0.22 \\
\hline Poland & 0.01 & 0.09 & 0.04 & 0.00 & 0.00 & 0.93 & 0.08 & 0.02 & 0.13 & 0.54 & 0.10 & 2.11 & 0.00 & 0.38 & 0.07 & 0.19 \\
\hline Portugal & 0.09 & 0.05 & 0.09 & 0.02 & 0.05 & 0.03 & 0.12 & 0.02 & 0.05 & 0.34 & 0.16 & 0.31 & 0.07 & 0.01 & 0.02 & 0.57 \\
\hline Romania & 0.00 & 0.03 & 0.13 & 0.04 & 0.20 & 0.27 & 0.06 & 0.00 & 0.06 & 1.39 & 0.08 & 4.02 & 0.22 & 0.21 & 0.06 & 0.40 \\
\hline Russia & 0.00 & 0.00 & 0.00 & 0.00 & 0.01 & 0.15 & 0.02 & 0.00 & 0.03 & 0.22 & 0.22 & . & 0.01 & 0.08 & 0.03 & 0.29 \\
\hline Singapore & 0.11 & 0.00 & 0.12 & 0.06 & 0.08 & 0.07 & 10.20 & 1.98 & . & 6.42 & 1.41 & 0.20 & 0.04 & 0.00 & 0.00 & 0.32 \\
\hline Slovak Rep. & 0.03 & 0.09 & 0.06 & 0.00 & 0.00 & 16.03 & 0.08 & 0.01 & 0.10 & 1.14 & 0.12 & 8.91 & 0.00 & . & 0.06 & 0.11 \\
\hline Slovenia & 0.01 & 0.09 & 0.07 & 0.00 & 0.00 & 1.55 & 0.12 & 0.01 & 0.20 & 0.60 & 0.12 & 1.70 & 0.00 & 0.70 & 0.09 & 0.30 \\
\hline South Africa & 0.01 & 0.00 & 0.15 & 0.00 & 0.00 & 0.02 & 0.15 & 0.02 & 0.10 & 0.48 & 0.29 & 0.03 & 0.00 & 0.00 & 0.01 & 0.19 \\
\hline Spain & 0.24 & 0.04 & 0.17 & 0.03 & 0.05 & 0.04 & 0.13 & 0.03 & 0.21 & 0.20 & 0.13 & 0.29 & 0.06 & 0.02 & 0.04 & 0.29 \\
\hline Sweden & 0.03 & 0.01 & 0.03 & 0.08 & 0.08 & 0.11 & 0.09 & 0.02 & 0.10 & 0.16 & 0.13 & 0.27 & 0.06 & 0.03 & 0.00 & 0.14 \\
\hline Switzerland & 0.03 & 0.01 & 0.03 & 0.00 & 0.00 & 0.09 & 0.19 & 0.02 & 0.04 & 0.13 & 0.15 & 0.35 & 0.01 & 0.04 & 0.01 & 0.13 \\
\hline Thailand & 0.06 & 0.00 & 0.03 & 0.01 & 0.01 & 0.04 & . & 0.33 & 0.54 & 1.55 & 0.44 & 0.44 & 0.02 & 0.00 & 0.01 & 0.00 \\
\hline Tunisia & 0.00 & 0.06 & 0.33 & 0.00 & 0.00 & 0.11 & 0.06 & 0.01 & 0.07 & 0.21 & 0.21 & 0.69 & 0.00 & 0.01 & 0.04 & 0.27 \\
\hline Turkey & 0.02 & 0.02 & 0.04 & 0.00 & 0.00 & 0.06 & 0.05 & 0.01 & 0.09 & 0.42 & 0.17 & 1.22 & 0.01 & 0.01 & 0.02 & 0.23 \\
\hline UK & 0.05 & 0.00 & 0.03 & 0.03 & 0.03 & 0.06 & 0.20 & 0.15 & 0.17 & 0.35 & 0.26 & 0.24 & 0.03 & 0.01 & 0.01 & 0.15 \\
\hline US & 0.88 & 0.03 & 0.03 & 0.16 & 0.22 & 0.01 & 0.19 & 0.13 & 0.14 & 0.37 & 0.11 & 0.07 & 0.21 & 0.00 & 0.03 & 0.16 \\
\hline Venezuela & 0.37 & 0.02 & 0.39 & . & . & 0.00 & 0.01 & 0.00 & 0.01 & 0.11 & 0.03 & 0.00 & . & 0.00 & 0.06 & 0.71 \\
\hline
\end{tabular}




\section{Table 5C: Cheap-Import Effect Statistics (Summary Statistics)}

\begin{tabular}{|c|c|c|c|c|c|c|c|c|c|c|c|c|c|c|c|c|}
\hline & \multicolumn{16}{|c|}{ CRISIS EVENTS } \\
\hline & $\begin{array}{c}\text { Mexico } \\
1994\end{array}$ & $\begin{array}{c}\text { Ecuad. } \\
1995\end{array}$ & $\begin{array}{c}\text { Argent. } \\
1995\end{array}$ & $\begin{array}{c}\text { Venez. } \\
1995\end{array}$ & $\begin{array}{c}\text { Venez. } \\
1997\end{array}$ & $\begin{array}{c}\text { Czech } \\
1997\end{array}$ & $\begin{array}{l}\text { Thail. } \\
1997\end{array}$ & $\begin{array}{c}\text { Philip. } \\
1997\end{array}$ & $\begin{array}{c}\text { Indon. } \\
1997\end{array}$ & $\begin{array}{c}\text { Korea } \\
1997\end{array}$ & $\begin{array}{c}\text { India } \\
1998\end{array}$ & $\begin{array}{c}\text { Russia } \\
1998\end{array}$ & $\begin{array}{c}\text { Venez. } \\
1998\end{array}$ & $\begin{array}{c}\text { Slovak } \\
1998\end{array}$ & $\begin{array}{c}\text { Ecuad. } \\
1998\end{array}$ & $\begin{array}{c}\text { Brazil } \\
1999\end{array}$ \\
\hline Mean & 0.11 & 0.04 & 0.17 & 0.08 & 0.11 & 0.45 & 0.42 & 0.10 & 0.22 & 0.82 & 0.37 & 1.11 & 0.12 & 0.18 & 0.04 & 0.35 \\
\hline Std. Dev. & 0.22 & 0.09 & 0.32 & 0.26 & 0.29 & 2.15 & 1.41 & 0.30 & 0.30 & 1.40 & 0.87 & 2.42 & 0.35 & 0.71 & 0.09 & 0.42 \\
\hline Minimum & 0.00 & 0.00 & 0.00 & 0.00 & 0.00 & 0.00 & 0.01 & 0.00 & 0.00 & 0.11 & 0.02 & 0.00 & 0.00 & 0.00 & 0.00 & 0.04 \\
\hline Maximum & 1.04 & 0.42 & 2.17 & 1.53 & 1.47 & 16.03 & 10.20 & 1.98 & 1.61 & 7.60 & 5.70 & 15.01 & 1.75 & 4.98 & 0.40 & 2.59 \\
\hline
\end{tabular}

\begin{tabular}{lc}
\hline \multicolumn{2}{c}{ Sample Statistics } \\
\hline Mean & 0.30 \\
Standard Deviation & 1.05 \\
Minimum & 0.00 \\
Maximum & 16.03 \\
\hline
\end{tabular}




\section{Table 6}

Regression Results ${ }^{\mathrm{a}}$

\begin{tabular}{|c|c|c|c|c|c|c|c|}
\hline & (1) & (2) & (3) & (4) & (5) & (6) & (7) \\
\hline Competitiveness & $-0.042 * *$ & $-0.052 * *$ & $-0.065 * *$ & $-0.049 * *$ & $-0.066 * *$ & $-0.056^{* *}$ & $-0.067 * *$ \\
\hline Effect & $(0.016)$ & $(0.018)$ & $(0.020)$ & $(0.018)$ & $(0.020)$ & $(0.019)$ & $(0.020)$ \\
\hline Income & -0.514 & $-1.021^{* *}$ & $-1.136^{*}$ & $-0.964 * *$ & $-1.256^{*}$ & $-1.095^{*}$ & $-1.243^{*}$ \\
\hline Effect & $(0.332)$ & $(0.360)$ & $(0.557)$ & $(0.365)$ & $(0.548)$ & $(0.536)$ & $(0.571)$ \\
\hline Cheap-import & 0.083 & $0.588 *$ & 0.446 & $0.525^{*}$ & 0.566 & 0.470 & 0.553 \\
\hline Effect & $(0.235)$ & $(0.262)$ & $(0.387)$ & $(0.268)$ & $(0.379)$ & $(0.383)$ & $(0.409)$ \\
\hline Private Credit & & $-1.536^{* *}$ & & & $-1.779 * *$ & & -2.373 \\
\hline Growth & & $(0.535)$ & & & $(0.535)$ & & $(1.788)$ \\
\hline Government & & 2.718 & & 2.658 & & & 6.428 \\
\hline Consumption / GDP & & $(2.910)$ & & $(3.005)$ & & & $(4.063)$ \\
\hline Current Account & & 2.754 & & & -0.304 & 5.133 & 3.469 \\
\hline Surplus / GDP & & $(3.382)$ & & & $(4.923)$ & $(3.424)$ & $(5.076)$ \\
\hline Bank Reserves / & & -1.069 & & -1.299 & & & 0.650 \\
\hline Assets & & $(1.591)$ & & $(1.637)$ & & & $(2.163)$ \\
\hline Private Capital & & -0.100 & & 0.564 & 0.937 & & 0.362 \\
\hline Inflows / GDP & & $(0.690)$ & & $(0.580)$ & $(1.307)$ & & $(1.429)$ \\
\hline Domestic Credit & & & $-1.455^{*}$ & 0.280 & & 0.328 & 2.142 \\
\hline Growth & & & $(0.687)$ & $(1.106)$ & & $(1.275)$ & $(1.728)$ \\
\hline Government & & & -5.002 & & -3.375 & 0.161 & 1.289 \\
\hline Surplus / GDP & & & $(4.661)$ & & $(4.682)$ & $(4.218)$ & $(5.153)$ \\
\hline Money Supply (M2) / & & & 1.647 & & 0.759 & 1.169 & 0.214 \\
\hline Reserves & & & $(1.568)$ & & $(1.539)$ & $(1.557)$ & $(2.015)$ \\
\hline Openness (Total & & & $1.080^{*}$ & & 0.786 & & 0.524 \\
\hline Trade / GDP) & & & $(0.440)$ & & $(0.512)$ & & $(0.516)$ \\
\hline Growth in GNP & & & & -9.090 & -6.823 & & -6.199 \\
\hline Per Capita & & & & $(6.175)$ & $(7.421)$ & & $(7.566)$ \\
\hline Inflation & & & & $-0.275^{*}$ & & $-0.284^{*}$ & -0.181 \\
\hline (in CPI) & & & & $(0.130)$ & & $(0.143)$ & $(0.195)$ \\
\hline Observa & 796 & 727 & 469 & 727 & 467 & 468 & 460 \\
\hline$R^{2}$ & 0.25 & 0.27 & 0.20 & 0.27 & 0.22 & 0.20 & 0.23 \\
\hline
\end{tabular}

NOTE: (a) Standard errors are White-adjusted for heteroscedasticity. All specifications also include period dummy variables (with the Brazilian crisis as the excluded variable). Variables defined in Appendix A. ** and * indicate significance at the 1 and 5 percent levels respectively. 
Table 7

\section{Country Examples: Predicted Trade and Macroeconomic Effects ${ }^{\mathrm{a}}$}

\begin{tabular}{|c|c|c|c|c|c|c|c|}
\hline & \multicolumn{3}{|c|}{ Predicted Weekly Trade Effects: } & \multicolumn{3}{|c|}{ Total Predicted Weekly Return from: } & \multirow{2}{*}{$\begin{array}{c}\text { Actual Average } \\
\text { Weekly Return } \\
\text { (7) }\end{array}$} \\
\hline & $\begin{array}{c}\text { Competitiveness } \\
\text { (1) }\end{array}$ & $\begin{array}{c}\text { Income } \\
(2)\end{array}$ & $\begin{array}{c}\text { Cheap-import } \\
\text { (3) }\end{array}$ & $\begin{array}{l}\text { Trade } \\
\text { (4) }\end{array}$ & $\begin{array}{l}\text { Macro Controls } \\
\text { (5) }\end{array}$ & $\begin{array}{c}\text { Full Model }^{\mathrm{b}} \\
\text { (6) }\end{array}$ & \\
\hline \multicolumn{8}{|l|}{ Thai Crisis } \\
\hline Korea & -0.35 & -0.52 & 0.15 & -0.72 & -0.17 & 4.53 & 4.67 \\
\hline Malaysia & -2.11 & -3.24 & 1.72 & -3.63 & -0.29 & 1.50 & -1.53 \\
\hline \multicolumn{8}{|c|}{ Russian Crisis } \\
\hline Finland & -0.41 & -2.52 & 1.58 & -1.34 & 0.70 & 0.83 & -4.43 \\
\hline Poland & -0.27 & -1.52 & 1.24 & -0.55 & -0.27 & 0.65 & -5.87 \\
\hline \multicolumn{8}{|c|}{ Brazilian Crisis } \\
\hline Argentina & -0.40 & -2.63 & 1.53 & -1.50 & -0.02 & -4.61 & -5.56 \\
\hline Chile & -0.25 & -1.07 & 0.89 & -0.43 & -0.07 & -3.59 & -3.26 \\
\hline
\end{tabular}

NOTES: (a) Predicted impact on weekly stock market indices based on out-of-sample coefficient estimates using the model in column 2 of Table 6.

(b) Full model includes trade and macroeconomic variables, as well as the crisis-specific dummy variables. 


\section{Table 8 \\ Sensitivity Tests ${ }^{\mathrm{a}}$}

\begin{tabular}{|c|c|c|c|c|c|c|c|}
\hline & $\begin{array}{c}\text { Base } \\
\text { Results } \\
\text { (1) }\end{array}$ & $\begin{array}{c}\text { Exclude } \\
\text { Outliers } \\
\text { for } \\
\text { Compete }^{\text {b }} \\
\text { (2) }\end{array}$ & $\begin{array}{c}\text { Exclude } \\
\text { Major Oil } \\
\text { Exporters }^{\mathrm{c}} \\
\text { (3) }\end{array}$ & $\begin{array}{l}\text { Redefine } \\
\text { Income }^{\text {Effect }}{ }^{\mathrm{d}} \\
\text { (4) }\end{array}$ & $\begin{array}{c}\text { Add } \\
\text { OECD } \\
\text { dummy }\end{array}$ & $\begin{array}{c}\text { Weight } \\
\text { Trade } \\
\text { Variables } \\
\text { (6) }\end{array}$ & $\begin{array}{c}\text { Add } \\
\text { Regional }^{\text {Dummies }}{ }^{\mathrm{f}} \\
\text { (7) }\end{array}$ \\
\hline Competitiveness & $-0.052 * *$ & $-0.054 *$ & $-0.054 * *$ & $-0.062 * *$ & $-0.049 * *$ & $-0.228^{*}$ & $-0.049 * *$ \\
\hline Effect & $(0.018)$ & $(0.022)$ & $(0.021)$ & $(0.018)$ & $(0.018)$ & $(0.104)$ & $(0.017)$ \\
\hline Income & $-1.021^{* *}$ & $-1.012 * *$ & $-1.022 * *$ & $-0.251 * *$ & $-1.027 * *$ & $-0.006^{*}$ & $-1.041^{* *}$ \\
\hline Effect & $(0.360)$ & $(0.356)$ & $(0.376)$ & $(0.097)$ & $(0.359)$ & $(0.003)$ & $(0.358)$ \\
\hline Cheap-import & $0.588^{*}$ & $0.590 *$ & $0.597^{*}$ & 0.219 & $0.607^{*}$ & -0.468 & $0.616^{*}$ \\
\hline Effect & $(0.262)$ & $(0.260)$ & $(0.275)$ & $(0.160)$ & $(0.263)$ & $(1.066)$ & $(0.261)$ \\
\hline Private Credit & $-1.536^{* *}$ & $-1.546^{* *}$ & $-1.633 * *$ & $-1.383^{* *}$ & $-1.407^{*}$ & $-1.491 * *$ & $-1.783 * *$ \\
\hline Growth & $(0.535)$ & $(0.535)$ & $(0.552)$ & $(0.497)$ & $(0.560)$ & $(0.548)$ & $(0.539)$ \\
\hline $\begin{array}{l}\text { Government } \\
\text { Consumption / GDP }\end{array}$ & $\begin{array}{c}2.718 \\
(2.910)\end{array}$ & $\begin{array}{c}2.681 \\
(2.913)\end{array}$ & $\begin{array}{c}2.955 \\
(3.012)\end{array}$ & $\begin{array}{c}2.317 \\
(2.898)\end{array}$ & $\begin{array}{c}2.166 \\
(2.941)\end{array}$ & $\begin{array}{c}2.957 \\
(2.953)\end{array}$ & $\begin{array}{l}-2.275 \\
(4.411)\end{array}$ \\
\hline $\begin{array}{l}\text { Current Account } \\
\text { Surplus / GDP }\end{array}$ & $\begin{array}{c}2.754 \\
(3.382)\end{array}$ & $\begin{array}{c}2.519 \\
(3.398)\end{array}$ & $\begin{array}{l}2.138 \\
(3.924)\end{array}$ & $\begin{array}{c}1.710 \\
(3.351)\end{array}$ & $\begin{array}{l}2.321 \\
(3.440)\end{array}$ & $\begin{array}{c}1.641 \\
(3.350)\end{array}$ & $\begin{array}{l}4.012 \\
(3.627)\end{array}$ \\
\hline $\begin{array}{l}\text { Bank Reserves / } \\
\text { Assets }\end{array}$ & $\begin{array}{l}-1.069 \\
(1.591)\end{array}$ & $\begin{array}{l}-1.008 \\
(1.589)\end{array}$ & $\begin{array}{l}-0.808 \\
(1.639)\end{array}$ & $\begin{array}{l}-1.265 \\
(1.590)\end{array}$ & $\begin{array}{l}-0.769 \\
(1.581)\end{array}$ & $\begin{array}{l}-0.929 \\
(1.616)\end{array}$ & $\begin{array}{l}-2.676 \\
(1.679)\end{array}$ \\
\hline $\begin{array}{l}\text { Private Capital } \\
\text { Inflows / GDP }\end{array}$ & $\begin{array}{l}-0.100 \\
(0.690)\end{array}$ & $\begin{array}{l}-0.078 \\
(0.690)\end{array}$ & $\begin{array}{c}0.074 \\
(0.727)\end{array}$ & $\begin{array}{l}-0.256 \\
(0.688)\end{array}$ & $\begin{array}{l}-0.286 \\
(0.698)\end{array}$ & $\begin{array}{l}-0.174 \\
(0.694)\end{array}$ & $\begin{array}{l}-0.052 \\
(0.756)\end{array}$ \\
\hline OECD dummy & & & & & $\begin{array}{c}0.371 \\
(0.303)\end{array}$ & & \\
\hline Observations & 727 & 722 & 691 & 727 & 727 & 727 & 727 \\
\hline$R^{2}$ & 0.27 & 0.26 & 0.26 & 0.27 & 0.27 & 0.26 & 0.28 \\
\hline
\end{tabular}

NOTES: (a) Standard errors are White-adjusted for heteroscedasticity. All specifications also include period dummy variables (with the Brazilian crisis as the excluded variable). Variables defined in Appendix A. ** and * indicate significance at the 1 and 5 percent levels respectively.

(b) The five largest values for compete are excluded.

(c) Major oil exporters defined as countries for which the ratio of oil and gas exports to GDP is over 5 percent. Countries in the sample that qualify as major oil exporters are: Ecuador, Norway, Oman, and Venezuela.

(d) Income effect redefined as exports from country $n$ to the crisis country as a percent of total exports from country $n$.

(e) Trade variables weighted by currency and interest rate movements in the ground-zero country. See text for details.

(f) Regional dummy variables are: Africa, Australasia, Central and South Asia, East Asia, Former Communist Europe (including Russia), Latin and South America, North America, and Western Europe. The excluded region is the Middle East. 


\section{Table 9 \\ Alternate Crisis Events: \\ Crises Defined as $E M P_{n, t}>\mu_{E M P}+3 \sigma_{E M P}$}

\begin{tabular}{|c|c|}
\hline Mexico & 11/28/94-01/08/95, 01/16/95-01/29/95, 02/27/95-04/02/95,10/30/95-11/12/95 \\
\hline Ecuador (1) & $01 / 23 / 95-02 / 12 / 95,10 / 30 / 95-11 / 05 / 95,11 / 27 / 95-12 / 03 / 95,12 / 18 / 95-12 / 24 / 95$ \\
\hline Philippines (1) & $02 / 20 / 95-02 / 26 / 95$ \\
\hline Argentina & $02 / 27 / 95-03 / 12 / 95$ \\
\hline \multicolumn{2}{|c|}{ South Africa (1) 04/17/95-04/23/95, 02/12/96-02/18/96, 04/01/96-04/14/96 } \\
\hline Colombia & $12 / 04 / 95-12 / 10 / 95$ \\
\hline Venezuela (1) & $12 / 11 / 95-12 / 17 / 95,12 / 25 / 95-12 / 31 / 95,04 / 15 / 96-04 / 21 / 96$ \\
\hline \multicolumn{2}{|c|}{ South Africa (2) 04/15/96-04/28/96 } \\
\hline Ecuador (2) & 07/01/96-07/07/96 \\
\hline Venezuela (2) & 03/10/97-03/16/97, 05/12/97-05/18/97, 05/26/97-06/02/97, 11/10/97-11/16/97, 02/16/98-02/22/98 \\
\hline Czech Rep. & 05/19/97-06/01/97 \\
\hline Slovak Rep. (1) & 05/19/97-06/08/97 \\
\hline Thailand & 06/30/97-07/06/97, 12/08/97-12/14/97, 12/29/97-01/04/97 \\
\hline Philippines (2) & 07/07/97-07/13/97, 09/29/97-10/05/97, 12/08/97-12/14/97 \\
\hline Indonesia & $\begin{array}{l}\text { 08/11/97-08/31/97, 09/29/97-10/05/97, 12/08/97-12/14/97, 01/05/98-01/11/98, 01/19/98-01/25/98, } \\
02 / 09 / 98-02 / 22 / 98,03 / 02 / 98-03 / 08 / 98,03 / 30 / 98-04 / 05 / 98,04 / 13 / 98-04 / 19 / 98,05 / 04 / 98-05 / 10 / 98, \\
05 / 18 / 98-05 / 24 / 98,06 / 08 / 98-06 / 14 / 98\end{array}$ \\
\hline Brazil (1) & $10 / 27 / 97-11 / 30 / 97,12 / 15 / 97-12 / 21 / 97,09 / 07 / 98-09 / 27 / 98$ \\
\hline Russia (1) & $11 / 17 / 97-11 / 23 / 97,05 / 18 / 98-05 / 23 / 98,07 / 06 / 98-07 / 13 / 98,08 / 10 / 98-09 / 20 / 98$ \\
\hline Korea & $12 / 01 / 97-12 / 14 / 97,12 / 29 / 97-01 / 04 / 97$ \\
\hline India & $01 / 19 / 98-01 / 25 / 98$ \\
\hline Malaysia & 03/02/98-03/08/98 \\
\hline Venezuela (3) & 04/20/98-04/26/98, 06/15/98-06/21/98, 09/14/98-09/20/98 \\
\hline \multicolumn{2}{|c|}{ South Africa (3) 06/22/98-06/28/98 } \\
\hline \multicolumn{2}{|c|}{ Slovak Rep. (2) 09/14/98-10/04/98, 05/17/99-05/23/99 } \\
\hline Ecuador (3) & $\begin{array}{l}\text { 09/21/98-09/27/98, 10/19/98-10/25/98, 11/02/98-11/08/98, 01/11/99-01/17/99, 01/25/99-02/07/99, } \\
02 / 22 / 99-03 / 07 / 99\end{array}$ \\
\hline Norway & $12 / 07 / 98-12 / 13 / 98$ \\
\hline Russia (2) & $12 / 28 / 98-01 / 03 / 99$ \\
\hline Brazil (2) & $01 / 11 / 99-01 / 24 / 99,02 / 22 / 99-02 / 28 / 99$ \\
\hline
\end{tabular}

NOTE: See note to Table 1 for a full list of countries included in the sample. 


\section{Table 10}

\section{Alternate Crisis Events: Crises Defined as $E M P_{n, t}>\mu_{E M P}+1.5 \sigma_{E M P}$}

\begin{tabular}{|c|c|}
\hline \\
\hline \multicolumn{2}{|c|}{$\begin{array}{l}\text { Slovak Rep. (1) } 07 / 18 / 94-07 / 24 / 94 \\
\text { Poland } \\
09 / 12 / 94-09 / 18 / 94\end{array}$} \\
\hline India (1) & 09/19/94-09/25/94, 10/03/94-10/30/94, 12/05/94-12/25/94 \\
\hline Mexico (1) & $11 / 07 / 94-01 / 08 / 95,01 / 16 / 95-01 / 29 / 95,02 / 20 / 95-04 / 02 / 95,04 / 10 / 95-04 / 16 / 95,10 / 30 / 95-11 / 12 / 95$ \\
\hline Argentina & $12 / 19 / 94-12 / 25 / 94,02 / 27 / 95-03 / 26 / 95$ \\
\hline Thailand (1) & $01 / 09 / 95-01 / 15 / 95$ \\
\hline Ecuador (1) & 01/23/95-02/19/95, 09/18/95-09/24/95, 10/23/95-11/05/95, 11/13/95-12/03/95, 12/18/95-12/31/95 \\
\hline Venezuela (1) & $01 / 30 / 95-02 / 05 / 95,12 / 11 / 95-12 / 17 / 95,12 / 25 / 95-12 / 31 / 95$ \\
\hline Philippines (1) & $02 / 20 / 95-03 / 12 / 95,03 / 20 / 95-04 / 09 / 95$ \\
\hline \multicolumn{2}{|c|}{ South Africa (1) 03/27/95-04/23/95, 01/29/96-03/03/96 } \\
\hline Austria & $05 / 08 / 95-05 / 14 / 95$ \\
\hline Belgium & $05 / 08 / 95-05 / 14 / 95$ \\
\hline Norway (1) & 05/08/95-05/14/95 \\
\hline Switzerland & 05/08/95-05/14/95 \\
\hline India (2) & $10 / 16 / 95-10 / 22 / 95,10 / 30 / 95-11 / 05 / 95,12 / 25 / 95-12 / 31 / 95,01 / 29 / 96-02 / 04 / 96,02 / 19 / 96-02 / 25 / 96,03 / 04 / 96-03 / 10 / 96$ \\
\hline Colombia (1) & $11 / 27 / 95-12 / 24 / 95,02 / 05 / 96-02 / 11 / 96,02 / 26 / 96-03 / 03 / 96$ \\
\hline \multicolumn{2}{|c|}{ South Africa (2) 03/25/96-04/28/96, 07/08/96-07/14/96, 07/22/96-07/28/96 } \\
\hline Venezuela (2) & 04/15/96-04/21/96, 03/10/97-03/16/97 \\
\hline Greece (1) & $05 / 20 / 96-05 / 26 / 96,11 / 25 / 96-12 / 01 / 96,12 / 16 / 96-12 / 22 / 96$ \\
\hline Ecuador (2) & 07/01/96-07/07/96 \\
\hline New Zealand & $01 / 20 / 97-01 / 26 / 97$ \\
\hline Thailand (2) & 02/03/97-02/09/97, 06/30/97-07/06/97, 07/28/97-08/03/97, 08/11/97-08/24/97, 11/10/97-11/16/97, 12/08/97-12/14/97, 12/29/97-01/11/97 \\
\hline Colombia (2) & 02/24/97-03/02/97, 12/22/97-12/28/97 \\
\hline Slovak Rep. (2) & 03/24/97-04/20/97, 05/19/97-06/08/97 \\
\hline Russia (1) & 04/07/97-04/13/97, 10/13/97-10/19/97, 10/27/97-11/02/97, 11/10/97-11/17/97, 12/01/97-12/14/97 \\
\hline Czech Rep. & 05/12/97-06/01/97, 11/24/97-11/30/97 \\
\hline Venezuela (3) & 05/12/97-06/01/97, 11/10/97-11/16/97, 01/19/98-01/25/98,02/16/98-02/22/98,04/20/98-04/26/98 \\
\hline Philippines (2) & 06/30/97-07/13/97, 07/21/97-07/27/97, 08/25/97-08/31/97, 09/29/97-10/05/97, 12/08/97-12/14/97, 12/22/97-12/28/97,06/08/98-06/14/98 \\
\hline Malaysia & 07/07/97-07/20/97, 12/08/97-12/14/97, 12/29/97-1/11/98, 01/19/98-01/25/98, 03/02/98-03/08/98 \\
\hline Indonesia (1) & $\begin{array}{l}\text { 07/14/97-07/20/97, 08/11/97-09/21/97, 09/29/97-10/05/97, 10/13/97-10/19/97, 11/03/97-11/23/97, 12/01/97-12/14/97, 12/29/97-01/11/98, } \\
01 / 19 / 98-01 / 25 / 98,02 / 09 / 98-02 / 22 / 98,03 / 02 / 98-03 / 08 / 98,03 / 30 / 98-04 / 05 / 98,04 / 13 / 98-04 / 19 / 98,05 / 04 / 98-05 / 10 / 98,05 / 18 / 98-05 / 31 / 98, \\
06 / 08 / 98-06 / 14 / 98,06 / 22 / 98-06 / 28 / 98\end{array}$ \\
\hline Greece (2) & 09/15/97-09/21/97, 10/27/97-11/02/97, 08/10/98-08/16/98 \\
\hline Australia (1) & $10 / 20 / 97-10 / 26 / 97,07 / 20 / 98-07 / 26 / 98$ \\
\hline Mexico (2) & $10 / 20 / 97-10 / 26 / 97,08 / 17 / 98-09 / 13 / 98,09 / 28 / 98-10 / 04 / 98$ \\
\hline Brazil (1) & $10 / 27 / 97-12 / 28 / 97,08 / 31 / 98-10 / 25 / 98$ \\
\hline Korea (1) & $11 / 17 / 97-12 / 21 / 97,12 / 29 / 97-01 / 04 / 97,03 / 30 / 98-04 / 05 / 98$ \\
\hline Chile (1) & $11 / 24 / 97-12 / 07 / 97,12 / 15 / 97-12 / 28 / 97$ \\
\hline Norway (2) & $11 / 24 / 97-12 / 28 / 97$ \\
\hline Ecuador (3) & $\begin{array}{l}\text { 12/01/97-12/14/97, 12/22/97-12/28/97, 03/30/98-04/05/98, 05/11/98-05/17/98, 08/03/98-08/23/98, 08/31/98-09/13/98, 09/21/98-09/27/98, } \\
10 / 19 / 98-11 / 22 / 98\end{array}$ \\
\hline Singapore & $12 / 08 / 97-12 / 14 / 97,01 / 05 / 98-01 / 11 / 98$ \\
\hline India (3) & $01 / 12 / 98-01 / 25 / 98$ \\
\hline Colombia (3) & 03/30/98-04/12/98, 06/01/98-06/07/98, 08/31/98-09/13/98, 10/05/98-10/11/98 \\
\hline Russia (2) & 04/27/98-05/04/98, 05/18/98-05/31/98, 07/06/98-07/12/98, 08/10/98-09/20/98, 10/12/98-10/18/98, 12/28/98-01/03/99 \\
\hline South Africa (3) & ) 05/25/98-05/31/98, 06/08/98-07/05/98, 08/03/98-08/09/98, 08/24/98-08/30/98,09/28/98-10/04/98 \\
\hline Venezuela (4) & 06/15/98-06/21/98, 09/14/98-09/20/98, 11/30/98-12/06/98 \\
\hline Indonesia (2) & 07/20/98-07/26/98, 08/03/98-08/16/98, 11/02/98-11/08/98 \\
\hline Philippines (3) & 08/03/98-08/09/98 \\
\hline Canada & 08/17/98-08/30/98 \\
\hline Slovak Rep. (3) & 08/17/98-08/23/98, 09/14/98-10/04/98, 05/10/99-05/23/99 \\
\hline Israel & $10 / 05 / 98-10 / 11 / 98$ \\
\hline Australia (2) & $10 / 19 / 98-10 / 25 / 98$ \\
\hline Japan & $10 / 19 / 98-10 / 25 / 98,11 / 02 / 98-11 / 08 / 98$ \\
\hline Brazil (2) & $10 / 26 / 98-11 / 08 / 98,01 / 11 / 99-01 / 24 / 99,02 / 22 / 99-02 / 28 / 99$ \\
\hline Ecuador (4) & 11/30/98-12/13/98, 01/11/99-02/14/99, 02/22/99-03/07/99, 03/15/99-03/21/99, 03/29/99-04/04/99 \\
\hline Norway (3) & $11 / 30 / 98-12 / 13 / 98,12 / 21 / 98-12 / 27 / 98,06 / 21 / 99-06 / 27 / 99$ \\
\hline Chile (2) & $12 / 07 / 98-12 / 13 / 98,12 / 21 / 97-12 / 27 / 97,06 / 14 / 99-06 / 20 / 99$ \\
\hline Korea (2) & $12 / 21 / 98-12 / 27 / 98$ \\
\hline$\underline{\text { Peru }}$ & 01/04/99-01/10/99 \\
\hline
\end{tabular}




\section{Table 11}

\section{Regression Results: Alternate Crisis Definitions}

\begin{tabular}{|c|c|c|c|c|c|c|}
\hline \multirow[b]{2}{*}{ Competitiveness } & \multicolumn{3}{|c|}{$\begin{array}{c}\text { Crises defined as: } \\
E M P_{n, t}>\mu_{E M P}+3 \sigma_{E M P}\end{array}$} & \multicolumn{3}{|c|}{$\begin{array}{c}\text { Crises defined as: } \\
E M P_{n, t}>\mu_{E M P}+1.5 \sigma_{E M P}\end{array}$} \\
\hline & $\begin{array}{l}-0.056^{* *} \\
(0.020)\end{array}$ & $\begin{array}{l}-0.053^{*} \\
(0.024)\end{array}$ & $\begin{array}{l}-0.054^{*} \\
(0.023)\end{array}$ & $\begin{array}{l}-0.065^{*} \\
(0.033)\end{array}$ & $\begin{array}{l}-0.089 * \\
(0.039)\end{array}$ & $\begin{array}{l}-0.091^{*} \\
(0.040)\end{array}$ \\
\hline Income & $-0.927 * *$ & $-1.067^{*}$ & $-1.216^{*}$ & $-0.671 * *$ & $-0.724 * *$ & $-0.744 * *$ \\
\hline Effect & $(0.334)$ & $(0.489)$ & $(0.511)$ & $(0.203)$ & $(0.214)$ & $(0.215)$ \\
\hline Cheap-import & $0.582^{*}$ & 0.698 & 0.816 & $0.353^{*}$ & $0.344 *$ & $0.359^{*}$ \\
\hline Effect & $(0.276)$ & $(0.406)$ & $(0.423)$ & $(0.145)$ & $(0.163)$ & $(0.165)$ \\
\hline Private Credit & -0.092 & & -1.641 & -0.110 & & 0.191 \\
\hline Growth & $(0.604)$ & & $(1.314)$ & $(0.330)$ & & $(0.945)$ \\
\hline Government & 3.642 & & $7.693 *$ & -2.476 & & 0.102 \\
\hline Consumption / GDP & $(2.218)$ & & $(3.358)$ & $(1.393)$ & & $(2.100)$ \\
\hline Current Account & 3.969 & & 5.481 & -0.716 & & -0.372 \\
\hline Surplus / GDP & (2.493) & & $(3.419)$ & $(1.703)$ & & $(2.278)$ \\
\hline Bank Reserves / & 1.185 & & 2.360 & $-1.859 *$ & & -0.236 \\
\hline Assets & $(1.185)$ & & $(1.614)$ & $(0.837)$ & & $(1.105)$ \\
\hline Private Capital & 0.137 & & 0.409 & $0.161)$ & & -0.379 \\
\hline Inflows / GDP & $(0.437)$ & & $(0.859)$ & $(0.315$ & & $(0.623)$ \\
\hline Domestic Credit & & -0.459 & 1.438 & & 0.087 & -0.131 \\
\hline Growth & & $(0.938)$ & $(1.295)$ & & $(0.757)$ & $(0.781)$ \\
\hline Government & & -2.163 & 2.552 & & $6.354 *$ & $6.792 *$ \\
\hline Surplus / GDP & & $(2.895)$ & $(3.283)$ & & $(2.868)$ & $(3.424)$ \\
\hline Money Supply (M2) / & & 0.450 & -0.169 & & $2.169^{*}$ & $2.209 *$ \\
\hline Reserves & & $(1.399)$ & $(1.618)$ & & $(0.886)$ & $(1.081)$ \\
\hline Openness (Total & & 0.256 & -0.314 & & $0.436^{*}$ & $0.520^{*}$ \\
\hline Trade / GDP) & & $(0.305)$ & $(0.369)$ & & $(0.216)$ & $(0.249)$ \\
\hline Growth in GNP & & -0.674 & 1.417 & & 1.605 & 1.477 \\
\hline Per Capita & & (5.699) & $(6.212)$ & & (3.394) & $(3.604)$ \\
\hline Inflation & & 0.023 & 0.007 & & -0.038 & -0.036 \\
\hline (in CPI) & & $(0.146)$ & $(0.175)$ & & $(0.087)$ & $(0.131)$ \\
\hline Observations & 1245 & 809 & 797 & 2657 & 1726 & 1707 \\
\hline$R^{2}$ & 0.12 & 0.13 & 0.14 & 0.24 & 0.25 & 0.26 \\
\hline
\end{tabular}

NOTE: (a) Standard errors are White-adjusted for heteroscedasticity. All specifications also include period dummy variables (with the Brazilian crisis as the excluded variable). Variables defined in Appendix A. ** and * indicate significance at the 1 and 5 percent levels, respectively. 


\section{Table 12}

\section{Crisis Subgroups ${ }^{\mathrm{a}}$}

\section{Crises with a Weekly:}

\begin{tabular}{ccc}
\hline $\begin{array}{c}\text { Currency } \\
\text { Devaluation }\end{array} \mathbf{b} \mathbf{1 0} \%$ & & $\begin{array}{c}\text { Interest Rate } \\
\text { Increase }^{\mathbf{c}} \geq \mathbf{3 0} \%\end{array}$ \\
Mexico & Mexico \\
Venezuela (1) & & Ecuador (1) \\
Thailand & Argentina \\
Philippines & Venezuela (2) \\
Indonesia & Czech Republic \\
Korea & Philippines \\
Russia & Indonesia \\
Ecuador (2) & India \\
Brazil & Russia \\
& Venezuela (3) \\
& Slovak Republic \\
& Ecuador (2) \\
\hline
\end{tabular}

NOTES: $\quad$ (a) Based on the crisis events labeled in Table 1.

(b) Devaluation/depreciation measured as the nominal exchange rate based on U.S. dollars. See Section IV for further information.

(c) Interest rates are short-term and based on the difference between the spread with the short-term U.S. interest rate versus the same spread averaged over the previous year. See Section IV for further information. 


\section{Table 13 \\ Regression Results Based on Crisis Subgroups ${ }^{\mathrm{a}}$}

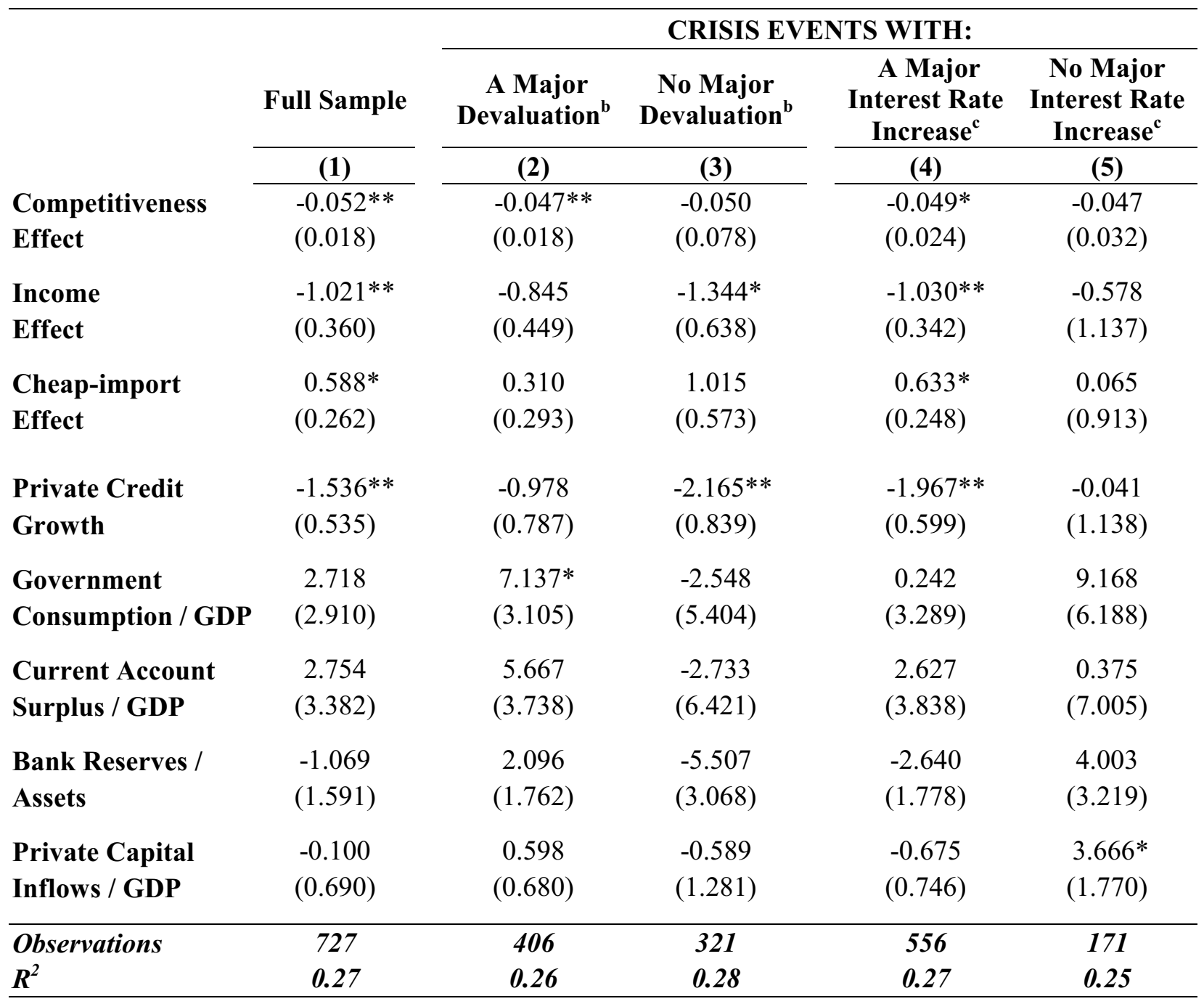

NOTES: (a) Standard errors are White-adjusted for heteroscedasticity. All specifications also include period dummy variables (with the Brazilian crisis as the excluded variable). Variables defined in Appendix A. ** and * indicate significance at the 1 and 5 percent levels, respectively.

(b) Major devaluation defined as an increase in the nominal U.S. dollar exchange rate of at least 10 percent within at least one week of the crisis. See Table 12 for the crisis list.

(c) Major interest rate increase defined as an increase of at least 30 percent within at least one week of the crisis in the short-term interest rate spread (compared to the U.S. rate) less the average spread over the past year. See Table 12 for the crisis list. 